Original Research Paper

\title{
Improve the Consumption of Cement and Sand in Massive Concrete
}

\author{
${ }^{1}$ Kaveh Ostad-Ali-Askari, ${ }^{2}$ Iman Niknejadi, ${ }^{3}$ Parisa Ashrafi, ${ }^{4}$ Amir Hossein Ashrafi, \\ ${ }^{5}$ Hossein Gholami, ${ }^{6}$ Morteza Soltani, ${ }^{7}$ Hossein Norouzi, ${ }^{8}$ Sona Pazdar and ${ }^{9}$ Shahide Dehghan
}

${ }^{1}$ Department of Environmental Health Sciences, Faculty of Communication, Arts and Sciences, Canadian University Dubai, Dubai, P. O. Box 117781, United Arab Emirates and Department of Civil Engineering, School of Engineering, American University in Dubai, Dubai, P. O. Box 28282 United Arab Emirates and Department of Irrigation, College of Agriculture, Isfahan University of Technology, Isfahan, 8415683111, Iran

${ }^{2}$ Department of Civil Engineering, Khomenishahr Branch, Islamic Azad University, Khomenishahr, Iran

${ }^{3}$ Department of Architecture and Art, University of Kashan, Kashan, Iran

${ }^{4}$ Department of Architecture and Urban Planning, Isfahan (Khorasgan) Branch, Islamic Azad University, Isfahan, Iran

${ }^{5,7}$ Department of Civil Engineering, Isfahan (Khorasgan) Branch, Islamic Azad University, Isfahan, Iran

${ }^{6}$ Department of Architectural Engineering, Shahinshahr Branch, Islamic Azad University, Shahinshahr, Iran

${ }^{8}$ Department of Civil Engineering, Aghigh University, Shahinshahr, Isfahan, Iran

${ }^{9}$ Department of Geography, Najafabad Branch, Islamic Azad University, Najafabad, Iran

Article history

Received: 19-10-2019

Revised: $28-07-2020$

Accepted: 06-08-2020

Corresponding Author:

Kaveh Ostad-Ali-Askari Department of Civil

Engineering, School of Engineering, American University in Dubai, Dubai, $\mathrm{P}$. O. Box 28282 United Arab Emirates and Department of Irrigation, College of Agriculture, Isfahan University of Technology, Isfahan,

8415683111, Iran

Email: ostadaliaskari.k@of.iut.ac.ir kaveh.oaa2000@gmail.com

\section{Introduction}

It article shows a technique for improving structure stage of condensed concrete organizations. Massive constructions in the universal and requirement to attain a maintainable progress and respectable stability for constructions, it is essential to recover the practical data of concrete in the world (Cardarelli et al., 2018). Bulk concrete combination design is very significant owing to its enormous capacity of depletion in concrete dams. An appropriate technique for bulk concrete combination plan that can encounter the plan, operation and financial requirement (Casson and Davies, 1986). Condensed concrete constructions, temperature effects water absorption might reason thermic strains. Mechanical properties and general heats has an essential effect on condensed concrete. Fracture conduct in condensed concrete construction is unavoidable (Cardarelli et al., 2018). Fractures would damage the thermic transmission aptitude of concrete. Generally, in the design of this concrete we do not face the issue of resistance. In contrast to proper performance, the lack of water leakage form concrete, control of the temperature of constructed concrete and so on there are some points that should be considered in the design of an appropriate concrete (Diederich, 2010). Compounding aggregates used in massive concrete are divided into different ranges depending on facilities and limitations imposed by technical specifications of each project. Increasing these divisions (as much as possible) is a positive step towards improvement of consumption of concrete. Nejad (2000) genetic algorithms is one of suitable method for controlling condensed concrete. Condensed concrete constructions for instance dams might be issue to initial stage furious owing to thermic pressures. But, condensed concrete includes very great capacities of concrete and important management human (Coo and Pheeraphan, 2016). So as to consider heat rises in condensed assemblies, portion of the cement in the concrete combination is frequently substituted by 
pozzolanic constituents. Owing to great bulk of concrete and logical intricate in manufacture of substantial arrangements, a precise and practicable process (Campos et al., 2018).

\section{Materials and Methods}

Ulm and Coussy's Pattern contemplates concrete such as a sensitive permeable broadcasting self-possessed of a dense essential of cement particles, apertures that might be completed by aquatic (Champion and Davis, 1958). Thermal distortion of a concrete structure alters sporadically, then alteration delays last appearance meteorology variation. Quantification and explanation of dam distortion information is an essential section of dam security assessment and has been investigated by different scholars (Fairbairn et al., 2004). For a concrete dam, the entire distortion is universally classified into different elements, containing a hydrostatic element, a thermal element and a time-related element. Figure 1 and 2 shows leading diagram of stone technological hazard features allowing expansion of peril-decreased plan and possibility-decreased building (Claybaugh et al., 2004).

Development of water absorption feedback is signified by an Arrhenius-kind calculation, determines thermicstimulation:

$$
\frac{d m}{d t}=\frac{d \zeta}{d t} m_{\infty}=\frac{1}{\eta(\zeta)} A(\zeta) \exp \left[-\frac{E_{a}}{R T}\right]
$$

wherever, $\mathrm{dm} / \mathrm{dt}$ is difference of minimum form; $0<\mathrm{n}<$ 1 is grade of water absorption otherwise the relative Among form of frame at a period $t$ regularized through form of frame while water absorption remains comprehensive such as $\xi(t)=m(t) / m_{\infty} ; \eta(\xi)$ is a viscidness period demonstrating rise in systemic obstruction CSH (Fairbairn et al., 2004).
The polycarboxylates was expressed numerous efficiency necessities such as water-decreasing and stability-sustaining (Brown, 2017; Grigoriadis, 2016). A tendency on the relative between the polymeric constructions and the ensuing presentation surely happens, nonetheless this one patterning is barely gained owing to indecision on constructions in addition to paste conformations. Superplasticizers, also recognized as great-span water-decreasing, combinations, improve the flexibility of concrete (Brown, 2017).

Self-compressing concretes must have high flexibility, consistency and should not separate. It is practicable to generate low stability self-compressing concrete, with the essential flexibility and decreased binder utilization, when inorganic excesses of metakaolin and fly ash are applied (Coo and Pheeraphan, 2015). Self-compressing concrete firstly seemed in the initial 1980's, ensuing original investigation that directed the expansion of concrete combinations then encounters together great flexibility besides great consistency (Breysse, 2012).

Blast oven ash sand has an unused hydraulicity below basic situations, the situation would better the extensive-time stability and permanence of concrete. The similar cementation proportion and the higher-border pressure proportion, the dynamism needed to practice minor crashes before the usual time burdening (Bujuan et al., 1996; Gadri and Bracci, 2017), in addition to the expended power in the determined zone, stay lesser for blast-furnace ash sand concrete than for usual concrete (Bracci et al., 1995; Goldstein and Smith, 1999).

Therefore, it is determined that the harm is completed to blast-furnace ash sand concrete throughout original burdening, in addition to in the persistent area throughout a tiredness procedure, is fewer than that completed toward standard concrete (Santos and Julio, 2007; 2013). Blastkiln ash gravel remains a result from steelworks and was dormant hydraulicity below basic situations (Fanelli and Giuseppetti, 1982; Najjar and Abdelgader, 2009).

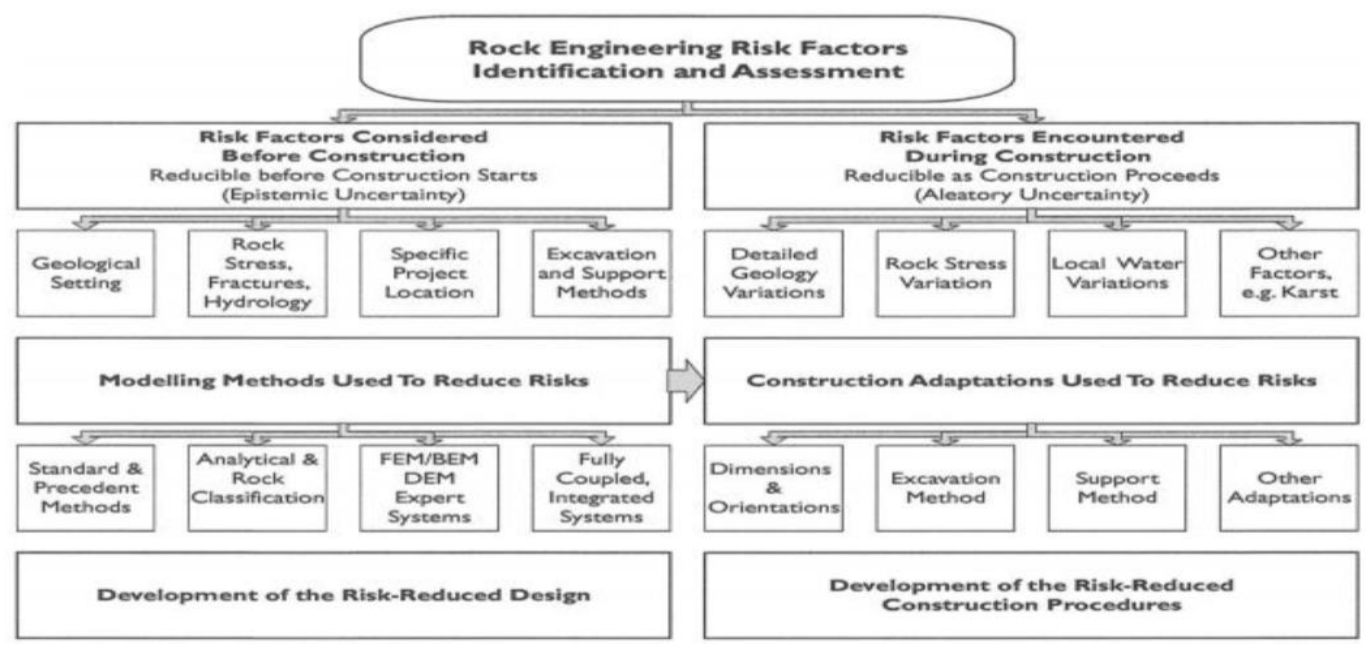

Fig. 1: Leading graph of rock scientific safety features allowing expansion of possibility-decreased plan and peril-decreased building (Hudson and Feng, 2015) 


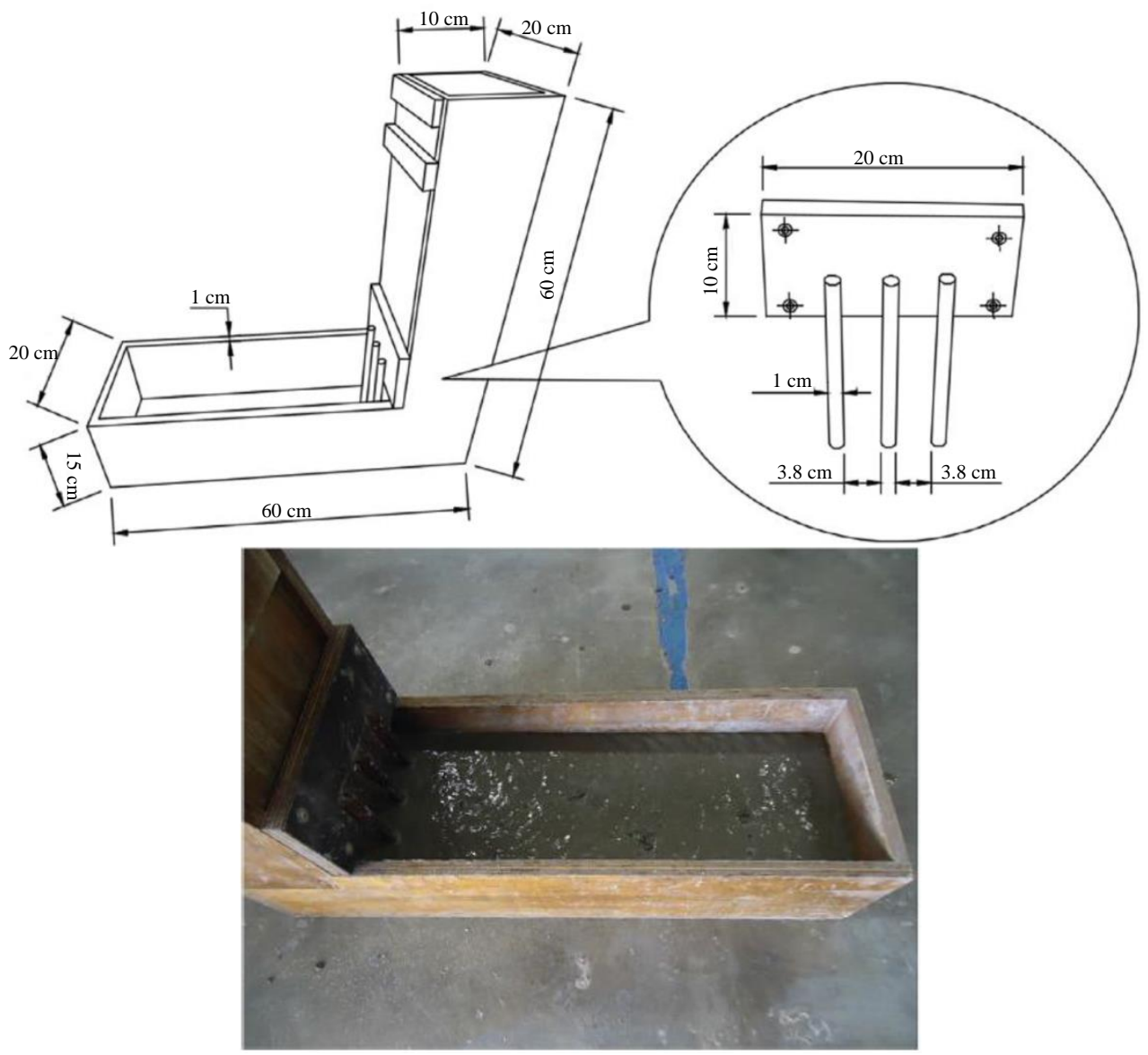

Fig. 2: Detail of concretes (Pelisser et al., 2018)
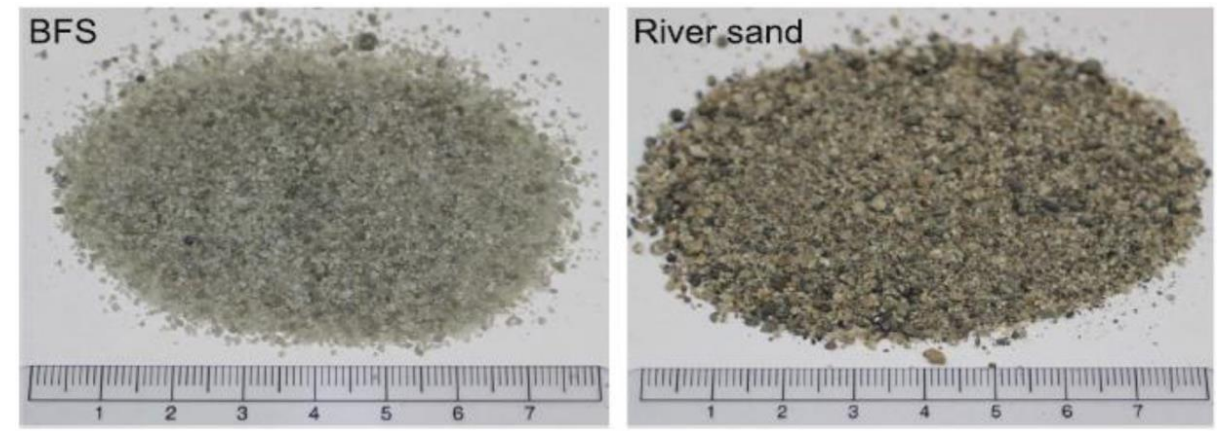

Fig. 3: The Blast-Furnace Slag sand (BFS) and River sand used in this study (Onoue, 2019)

Therefore, as soon as this one was applied for example a substance designed for physical, the alteration the area among sand and dough was enhanced. For the usage of explosion-kiln ash sand to extremely-lasting precast concrete yields, but the systems of these betterments require to be defined. For instance, when concrete with explosion-kiln ash sand (explosion-kiln ash sand concrete) is used to strengthen and formed concrete pieces, tiredness otherwise icing besides warming practices was possible issues. Figure 3 shows the Blast-
Furnace slag sand and Stream gravel applied in this subject (Onoue, 2019; Gu, 2006).

The construction of maintainable structure constituents, such as concrete, has drawn more and more consideration in the previous period. Recent concrete is powerfully reliant on the consistent performance of combinations (Bracci et al., 1995; Hariri-Ardebili and Saouma, 2016). The compressions of diminishing price and ecological effect, quickening structure timetables, plummeting concrete assignment work and refining concrete toughness have united to make 
combination practice virtual necessities (Berodier and Scrivener, 2014; Guoqiang et al., 1999).

\section{Results}

This factor is observational concept and it means that it is not possible to cover all the aggregates by paste and the stone aggregates remain on the concrete after the end of the vibration without entering into concrete volume. The negative results are (Nejad, 2000; Haselton, 2007; He, 2020):

- Creating vacant space in concrete and thus increasing the permeability and reducing its resistance

- Prolonging the vibration time and resulting damage to the machines

- Separation of grains

The reasons of this can be found in the following cases:

- The inappropriate graining in stone concretes or a huge change in the quality of these concretes compared to the primary design

- Change in the quality of sand

- Unsuitable design of concrete paste or percentage of stone grains mixing

Thus, so as to resolve the above issue through continuously controlling the quality of stone concretes and maintaining the quality of the sand in the permitted range it should be reconsidered in the mixing plan in order to make a suitable paste for granular stones (Abdelgader, 2016; He, 2020; Najjar et al., 2014).

Concrete interfacial roughness performs a considerable function in presenting to the recent-to-old concrete adhering. Superficial coarseness executes an essential feature in the treatment of concrete-to-concrete joints (Abu-Tair et al., 2000; Justnes, 1992). Procedures equal sand-blasting and hydrodemolition are generally modified towards update the superficial smoothness of the concrete layer (Poul, 2018; Qin, 2019). Formerly locating the recent concrete cover it stands usual to confirm the coarseness stage via optical examination (Abdul Awal, 1984; Najjar et al., 2014). Figure 1 Shows the automated laser quantification system with a stepping motors (bottom and right) and concrete floor models on the trial bed. Figure 4 Shows Tekscan sensor between bovine claw and concrete panel in a compaction engine (Franck and Belie, 2006; Gu et al., 2011). The detector is placed in a handle, which in turn is linked to the information attainment card of a private computer.

Considering that the water needed to solidify the cement much less the water used in concrete. if the water is not absorbed in concrete leads to water leakage from concrete and it will produce the following negative results (Nejad, 2000; Khayat and Libre, 2014; Satyarno et al., 2014):

- Problems in concrete

- Forming the cavity in concrete
- Increase permeability and reduce resistance

The causes of this can be found in following cases:

- Increasing the amount of water in the production of concrete relative to the water intended for initial mixing plan

- Shortage of aggregates or change its quality

- Not enough paste

- Increasing the moisture content of sand and increasing water entering and using less sand in concrete production.

Effective methods to solve these problems include (Nejad, 2000; Karsan and Jirsa, 1969):

- Improving the quality of sands

- Increasing the amount of cement

We propose which the electrical appliance ground discovery of tank aquatic seepage zones was applied such as a rational and impressive procedure to discover concrete barrier leakage. After examining the leakage remedy result of many dams, considered that promoting up vents of permeation transits in the headwaters level of the dam is the greatest considerable method (Bonaldi et al., 1977; He, 2017). In addition, distributing the outdated permeance, movements may considerably decrease the hazard of recent seepage passages happening (Berodier et al., 2019; Kang, 2019). The weakness lifetime of the compound pieces in aquatic leak is meaningfully lesser than that of the slab verified in a waterless situation. In the direction of additional comprehend the result of aquatic on decreasing the effectiveness of the glue, extra examinations are showed with an importance on aquatic-captivation and cut bulk in a damp situation (Abu-Tair et al., 2000; Najjar, 2016; Neville, 1995). The tiredness act of a concrete level can be impacted by aquatic seepage. Most researches considering fatigue applications exposed to aquatic concentrate on concrete or reinforced concrete memberships (Bièvre et al., 2017; Julio et al., 2004; Nowek et al., 2007; O'Malley and Abdelgader, 2010). But the tiredness conduct of steel-concrete compound portions might be impacted through aquatic seepage restricted investigation was shown to education the outcome of aquatic on the tiredness of a compound construction (Pereira et al., 2018; Popovics, 1973). Prepared that smooth fractures are often experimental in a concrete level, aquatic seepage seems to be made compound bridge portions (Abdurrahmn, 2014; Higgins and Mitchell, 2011). Figure 5 shows test condition (water leakage). Aquatic seepage from side to side the did track debilitated join of the cementitious sticky in continuity with tiredness danger (Yoshitake et al., 2016; Hoła et al., 2015; Niklasch and Herrmann, 2009). 


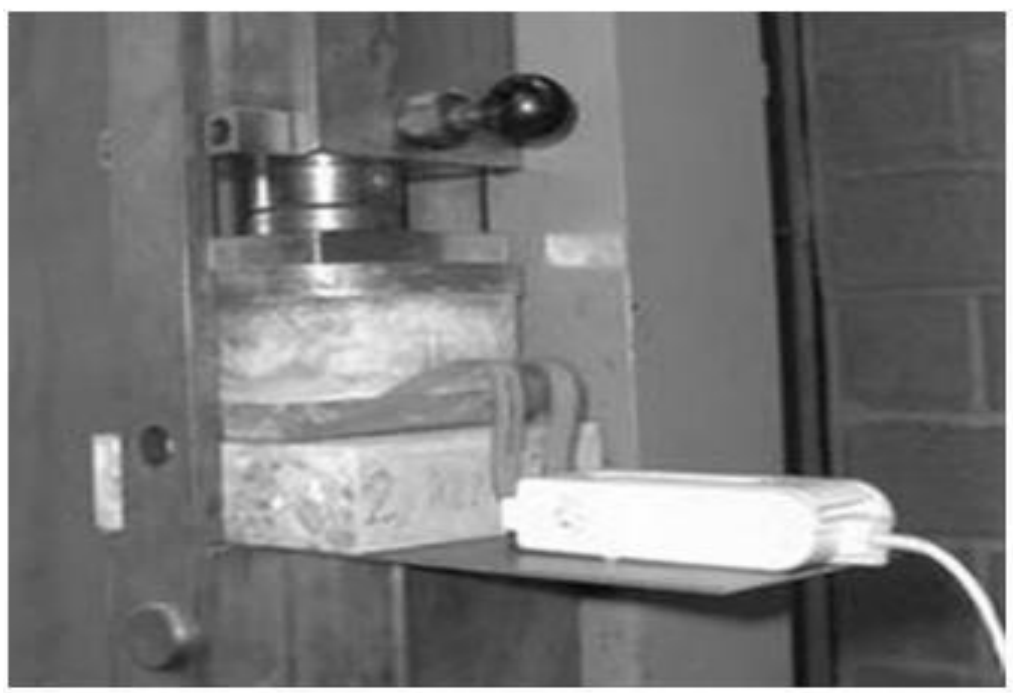

Fig. 4: Teks can sensor between bovine claw and concrete panel in a compaction engine. The detector is placed in a handle, which in turn is linked to the information attainment card of a private computer (Franck et al., 2008)

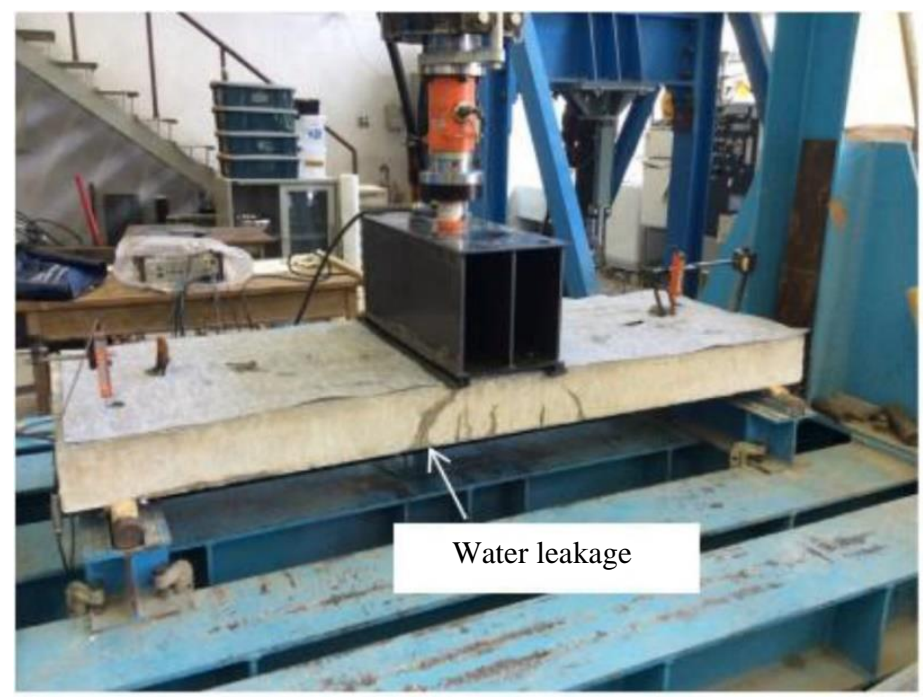

Fig. 5: test condition (water leakage) (Yoshitake et al., 2016)

Concrete paste is an adhesive agent in concrete. Reducing adhesion can lead to the following problems (Nejad, 2000; Joudi-Bahri et al., 2012):

- Separation of grains

- Problems in installing concrete

High adhesion also causes problems in the installation of concrete and in the event of problems with adhesion of concrete the paste should be examined (Jeon et al., 2009; Jiang et al., 2018; Najjar, 2009).

\section{Discussion}

Today structures are done by sprinkling concrete into shapes named formworks that are typically produced metal elements (Abdelgader, 2003; Jones et al., 2003). Flaws such as disrobing may perhaps system throughout the elimination of the shape if the superficial closeness among the concrete and the shape is great (Abdelgader, 2008; Hong et al., 2014). Create application of a recent achieve ductile examination, an association was recognized among the shape superficial useful signs and its stickiness inclination to concrete. The innovation of superficial examination is to describe the concrete-toshape stickiness by calculating the essential force to pull the concrete from the formwork external (Abdelgader, 2005; Issa et al., 2003; Lastra-González et al., 2017). The interfacial connection to concrete has been contrasted between simple and covered formwork. The pull-off ductile examination was established accomplished of position formwork coverings giving to their adherence to concrete 
(Spitz et al., 2018; Rivera et al., 2015; ACI, 2005; Wang and Liu, 2008; Matalkah and Soroushian, 2018).

Table 1 shows Biochemical structure and physical possessions of concretes. It considers kind of materials which affects concrete that Sio 2 has the highest impact for concrete. Table 2 shows Combination quantities of the cement pastes. It has 3 particles such as Cement, Fly ash, Water that it impacts concrete (Rivera et al., 2015). Table 3 shows Thermic conductivity values that Quartzite has the highest quantity. Dolomite has also highest impact after Quartzite (ACI Committee 207, 1993; ACI, 2005). Table 4 and 5 shows Chemical constructions of binders that the composition such as Cao, Sio2, Al2o3m, Mgo, Fe2o3, So3, $\mathrm{Na}_{2} \mathrm{O}, \mathrm{K}_{2} \mathrm{O}$, LOI. (Wang et al., 2019). Table 6 shows Chemical constructions that constitutes kind of materials such as $\mathrm{SiO}_{2}, \mathrm{CaO}$ and so on. Table 7 shows Combination project for the concrete and It includes Cement, Fine Aggregate, Coarse aggregate and so on. Table 8 shows Compactness, voids contented and water concentration volume trial consequences (Matalkah and Soroushian, 2018; IFSTTAR, 2018).

Table1: Chemical composition and physical properties of concretes (Rivera et al., 2015)

\begin{tabular}{|c|c|c|c|c|c|c|c|c|c|c|}
\hline Material & $\mathrm{SiO}_{2}$ & $\mathrm{Al}_{2} \mathrm{O}_{3}$ & $\mathrm{Fe}_{2} \mathrm{O}_{3}$ & $\mathrm{~K}_{2} \mathrm{O}$ & $\mathrm{CaO}$ & $\mathrm{MgO}$ & $\mathrm{Na}_{2} \mathrm{O}$ & $\mathrm{SO}_{3}$ & Specific gravity & Loss on ignition (\%) \\
\hline $\mathrm{OPC}$ & 20.39 & 6.01 & 3.15 & 0.75 & 63.25 & 1.30 & 0.15 & 2.35 & 3.12 & 1.72 \\
\hline $\mathrm{BC}$ & 28.30 & 2.80 & 2.19 & 0.40 & 54.10 & 1.18 & 0.54 & 0.74 & 2.90 & 9.23 \\
\hline FA-C & 33.10 & 11.60 & 6.53 & 0.80 & 28.50 & 1.66 & 1.39 & 7.69 & 2.37 & 7.08 \\
\hline FA-F & 55.80 & 21.00 & 8.31 & 1.07 & 5.87 & 2.70 & 1.54 & 0.44 & 2.39 & 1.01 \\
\hline
\end{tabular}

Table2: Mixture proportions of the cement pastes (Rivera et al., 2015)

\begin{tabular}{lcccc}
\hline Mixture ID & Cement $\left(\mathrm{kg} / \mathrm{m}^{3}\right)$ & Fly ash $(\%)$ & Fly ash $\left(\mathrm{kg} / \mathrm{m}^{3}\right)$ & Water $\left(\mathrm{kg} / \mathrm{m}^{3}\right)$ \\
\hline OPC & 1359.7 & 0 & 0.0 & 571.1 \\
BC & 1307.5 & 0 & 0.0 & 549.1 \\
$40-\mathrm{C}$ & 865.7 & 40 & 431.5 & 544.8 \\
$60-\mathrm{C}$ & 595.4 & 60 & 667.7 & 530.4 \\
$80-\mathrm{C}$ & 307.4 & 80 & 919.2 & 515.2 \\
$40-\mathrm{F}$ & 864.4 & 40 & 434.5 & 545.5 \\
$60-\mathrm{F}$ & 594.0 & 60 & 671.7 & 531.6 \\
$80-\mathrm{F}$ & 306.4 & 80 & 924.0 & 516.7 \\
\hline
\end{tabular}

Table 3: Thermic conductivity standards (ACI Committee 207, 1993; ACI, 2005)

\begin{tabular}{llc}
\hline Aggregate & Thermal conductivity, W/ $(\mathrm{m} \mathrm{k})$ & Thermal diffusivity, $\mathrm{m}^{2} / \mathrm{h}$ \\
\hline Quartzite & 3.5 & 0.0054 \\
Dolomite & 3.2 & 0.0047 \\
Calcareous & $2.6-3.3$ & 0.0046 \\
Granite & $2.2-2.7$ & 0.0040 \\
Rhyolite & 2.2 & 0.0033 \\
Basalt & $1.9-2.2$ & 0.0030 \\
\hline
\end{tabular}

Table 4: Biochemical structures of binders (wt\%) (Wang et al., 2019)

\begin{tabular}{llllllllll}
\hline Composition & $\mathrm{CaO}$ & $\mathrm{SiO}_{2}$ & $\mathrm{Al}_{2} \mathrm{O}_{3}$ & $\mathrm{MgO}$ & $\mathrm{Fe}_{2} \mathrm{O}_{3}$ & $\mathrm{SO}_{3}$ & $\mathrm{Na}_{2} \mathrm{O}$ & $\mathrm{k}_{2} \mathrm{O}$ & $\mathrm{LOI}$ \\
\hline ES-UHPC binder & 37.0 & 29.0 & 14.3 & 3.1 & 2.9 & 8.2 & 0.19 & 0.44 & 0.3 \\
N-UHPC binder & 50.1 & 34.4 & 5.2 & 3.2 & 2.3 & 2.1 & 0.14 & 0.44 & 2 \\
\hline
\end{tabular}

Table 5: Properties of steel fibers (Wang et al., 2019)

\begin{tabular}{llllll}
\hline Tensile strength/MPa & Elastic modulus $/ \mathrm{Gpa}$ & Density $/\left(\mathrm{kg} / \mathrm{m}^{3}\right)$ & Length $/ \mathrm{mm}$ & Diameter/um & Slenderness ratio \\
\hline 2500 & 200 & 7850 & 13 & 200 & 60 \\
\hline
\end{tabular}

Table 6: Biochemical structures (Matalkah and Soroushian, 2018)

\begin{tabular}{llllllllll}
\hline & $\mathrm{SiO}_{2}$ & $\mathrm{CaO}$ & $\mathrm{Al}_{2} \mathrm{O}_{3}$ & $\mathrm{Fe}_{2} \mathrm{O}_{3}$ & $\mathrm{MgO}$ & $\mathrm{K}_{2} \mathrm{O}$ & $\mathrm{Na}_{2} \mathrm{O}$ & $\mathrm{SO}_{3}$ & Blaine fineness, $\mathrm{cm}^{2} / \mathrm{g}$ \\
\hline OPC & 20.1 & 64.2 & 5.31 & 2.86 & 2.65 & 0.10 & 0.02 & 2.14 & 3870 \\
AAC & 35.2 & 28.1 & 13.6 & 4.03 & 3.73 & 1.14 & 8.89 & 0.53 & 3960 \\
\hline
\end{tabular}

Table 7: Mix design for the concrete (Matalkah and Soroushian, 2018)

\begin{tabular}{lc}
\hline Material & Quantity, $\mathrm{kg} / \mathrm{m} 3$ \\
\hline Cement & 400 \\
Fine aggregate & 910 \\
Coarse aggregate & 1100 \\
Water-to-cement ratio & $0.45-0.55$ \\
\hline
\end{tabular}


Table 8: Density, voids content and water absorption capacity test results (Matalkah and Soroushian, 2018)

\begin{tabular}{llll}
\hline & Density & voids $(\%)$ & Absorption $(\%)$ \\
\hline OPC concrete & 2.28 & 12.25 & 6.17 \\
AAC concrete & 2.30 & 14.07 & 5.74 \\
\hline
\end{tabular}

\section{Conclusions}

The concept of performance in the massive concrete differs slightly from other types of concrete. the reasons for this are (Nejad, 2000).

- Due to coarseness of grains and impossibility of mixing it. Transportation is carried out by silo bus or similar machines. This way of transferring itself creates a psychological limit on concrete (Abdelgader, 1999; Mazighi and Mihoubi, 2018, Stroeven, 2000).

Generally, a massive concrete examine overhead. You should contemplate the following points to achieve the goal (Nejad, 2000; Liu et al., 2019).

\section{Temperature of Concrete}

Temperature control in massive concrete can be achieved by lowering the temperature of concrete, plummeting the utilization of cement, controlling its temperature and change the amount of water and ice used (Nejad, 2000; Liu et al., 2009; Park et al., 1982; Paulay and Priestley, 1992).

\section{Amount of Water(ice)}

Water and ice consumption, in addition to the effect on the temperature directly affects the performance on the temperature so that the lack of it will result in serve reduction in the efficiency and the large amount of it will cause excessive moisture of the concrete and will make it difficult to carry and place the concrete (Nejad, 2000; Yoon and Kim, 2018).

\section{Amount of Concrete Paste}

The main component impacting the performance of concrete that in both cases the deficit or excess of that vibration will be difficult. Reduction in efficiency (Abdelgader, 1996; Meng et al., 2019), excessive adhesion and the lack of proper vibration include problems caused by an increase in the amount of paste. In contrast, the shortage of paste leads to the separation of grains and the possibility of vibration and formation of a coherent and homogeneous mass disappears (Nejad, 2000; Pant et al., 2013, Pelisser et al., 2012).

\section{Stone Grains}

The effect of the dimension of grains and its consumption along with the amount of concrete paste is understood that it mentioned before. In massive concrete as well as other concrete the round corner stones have better performance than the broken stones (Nejad, 2000; Lee and Oh, 2018; Shaker et al., 2018).

\section{Additives}

Along with lubricants and reducing the amount of water, less use of air-manufacturer concretes can have a good effect on performance of concrete (Nejad, 2000; Metha and Monteiro, 2006).

\section{Concrete Paste}

Concrete paste is the part of concrete which is responsible for filling the gap between aggregates and it contains cement and part of fine grains (Nejad, 2000; Mostofinejad, 2005).

\section{Mixing Plan}

Considering that mixing plan of massive concrete is almost the same as conventional concrete only a few points are mentioned in this section (Nejad, 2000; Morohashi et al., 2013).

Amount of Cement. As mentioned before, generally in massive concrete we do not face the problem of resistance. The fact that in addition to resistance and economics of the design they affect the amount of cement consumption are: Limitations of concrete temperature during construction and solidification, roughness of concrete and the water leakage from it (Nejad, 2000; Mostofinejad, 2005).

\section{Water and Ice}

The needed water can be determined depending on the performance the temperature and resistance (Selçuk and Gökçe, 2015; Yassin, 1994).

\section{Additives}

Depending on environment and specification required can be determined (Nejad, 2000; Molines and Medina, 2015).

\section{Stone Concretes}

The quality and consumption of these concretes play a crucial role in improving mixing plan of massive concrete so that the amount of cement and additives and ice consumption which is a major cost in production of concrete has an impact (Nejad, 2000; Moradloo et al., 2019).

\section{Mixing Percentage}

The granularity curve of the stone concretes is the final determinant of the mixing rate and the final curve of concrete. In the final curve it should be noted that the fracture does not occur with a sudden gradient change (Nejad, 2000; Moradloo et al., 2019). Figure 8 shows Ice (vague) and concrete precooled stationary categorized concrete mixer (right) (Schackow et al., 2016). Figure 9 Shows Component measurement diversity and exact shallow region of concrete elements (Singh et al., 2017; Sanchez and Sobolev, 2010). 


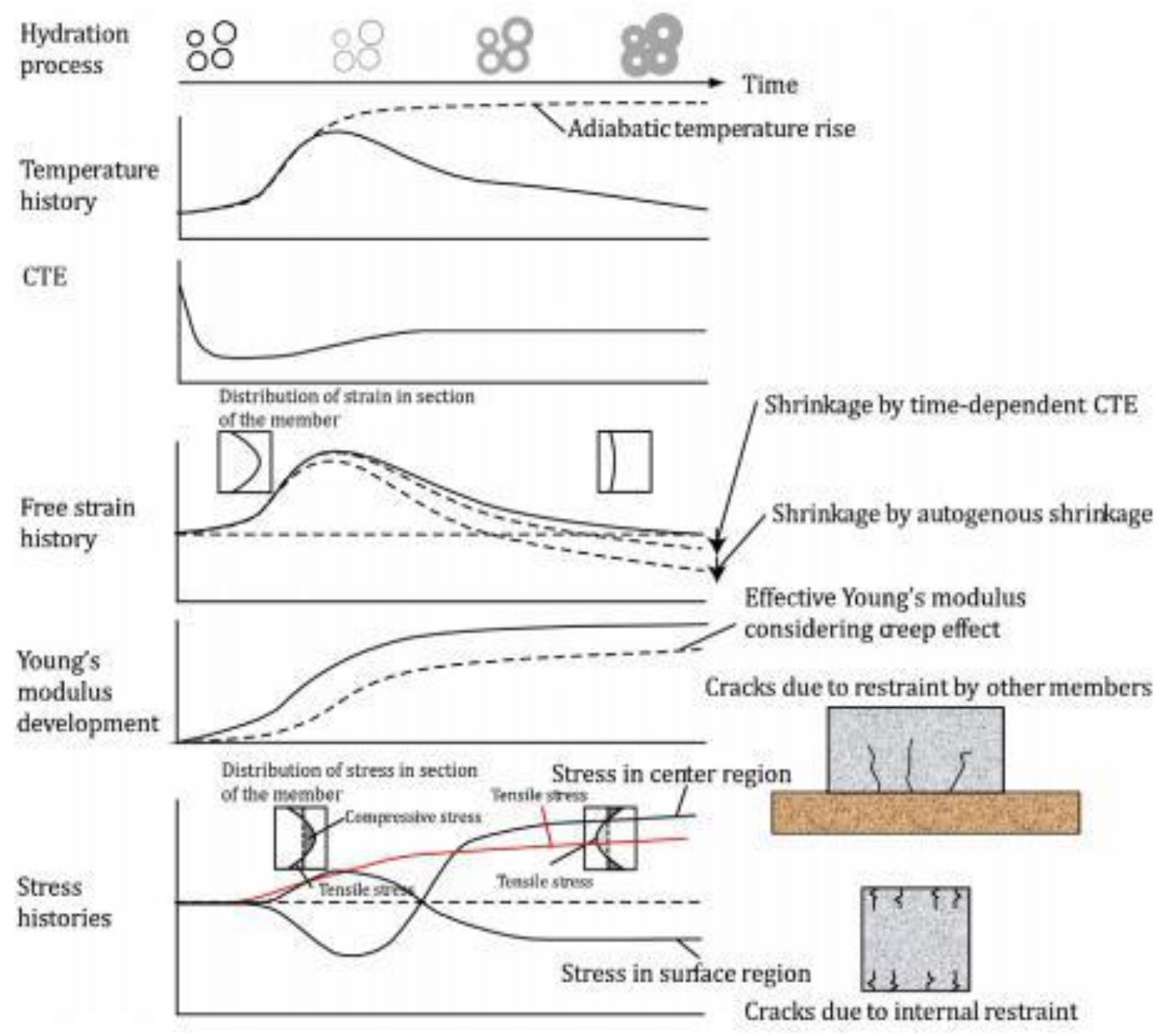

Fig. 6: The formal shape for the fracturing of mass concrete (Maruyama and Lura, 2019)

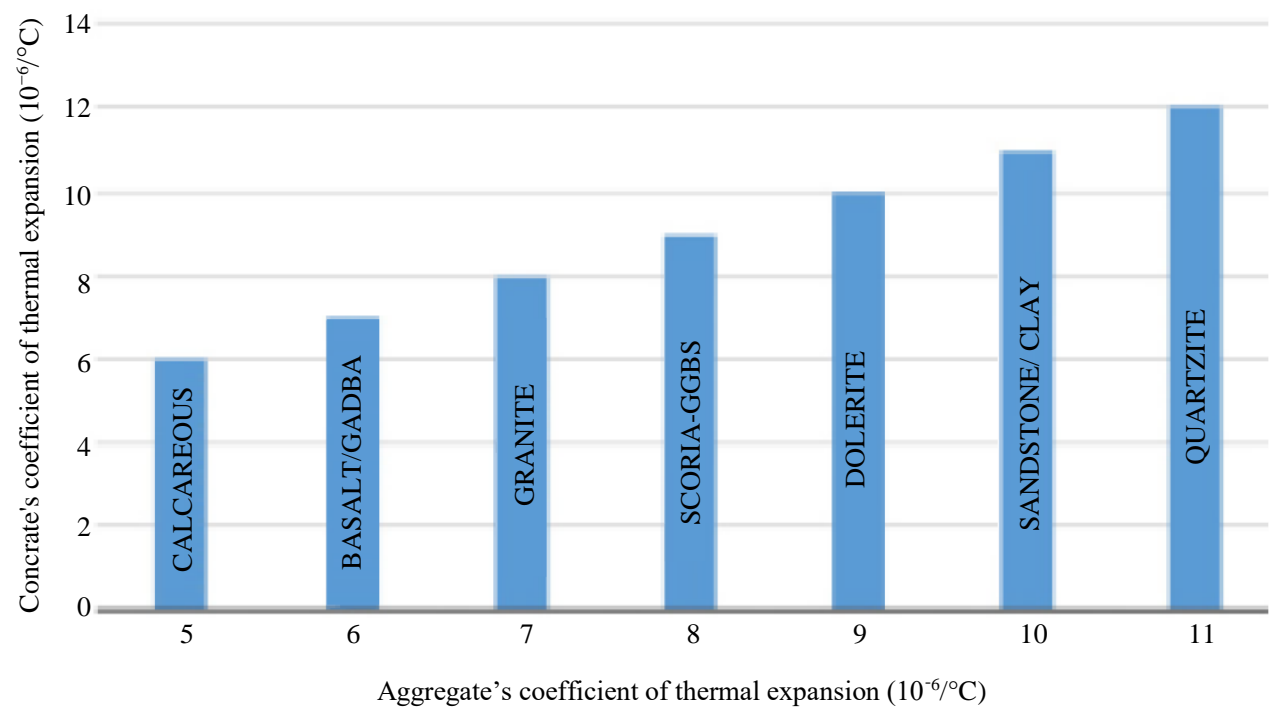

Fig. 7: Aggregate's influence in concrete (Metha and Monteiro, 2006) 

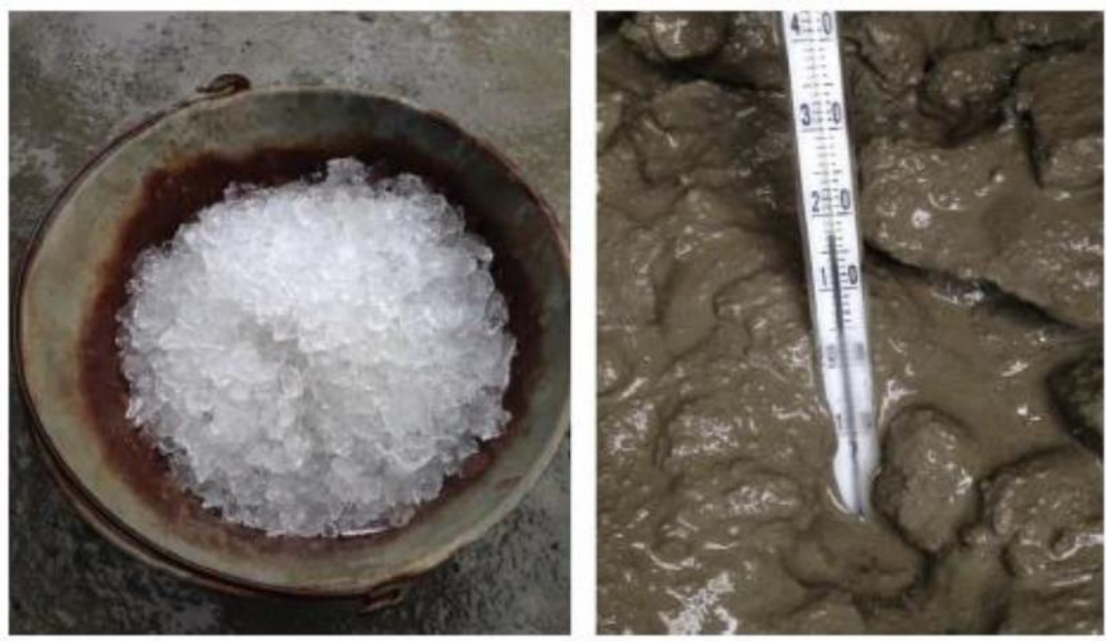

Fig. 8: Frost (absent) and concrete precooled static classified concrete blender (right) (Schackow et al., 2016)

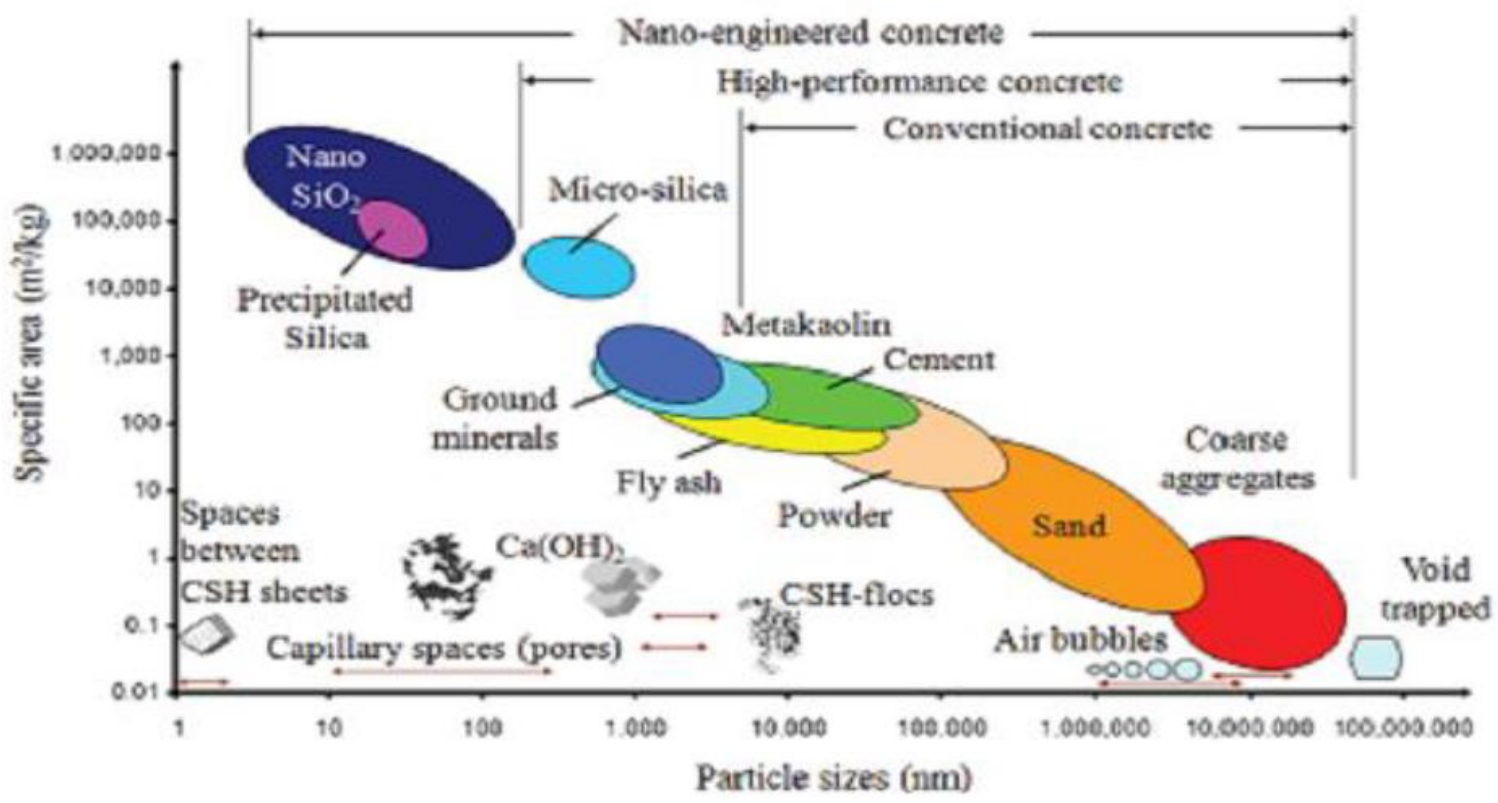

Fig. 9: Element dimension variety and precise superficial zone of concrete constituents (Singh et al., 2017; Sanchez and Sobolev, 2010)

The temperature of form concrete may rise considerably owing to the mixture of temperature freedom produced by cement hydration and thermic limitations for dense components might method adiabatic situations (Bayer, 2004; Zhu et al., 2019). This heat rise consequences in thermic distortion of physical memberships completed of concrete and that one effects together the kinetics of cement hydration. While the heat of content concrete rises formerly reductions once more, thermic straining happens (Alev et al., 2015; Wu et al., 2007). Owing to heat inclines segment concrete element, central element would originally enlarge outside membrane. Ductile pressures would accordingly rise membrane that might origin superficial fractures (Assawamartbunlue et al., 2015, Xu et al., 2012). Fractures happen in stage while heat remains cumulative. It be situated usually comparatively reedy and would near advanced while heat of entire concrete component balances. Attendance outside limitation, compressive pressures will rise dense concrete fundamental while heat rises (Baltazar et al., 2014; Wong and Lim, 2006). Condensed pressures would finally chance throughout ductile pressures while heat reduces toward balance by outside situation. It remains mostly produced through 
alteration concrete throughout heat rise and throughout heat reduce. While heat reduces, grade of absorbing water concrete to be advanced when reduction/sidle reduces grade of absorbing water (Basnet and Panthi, 2018; Wu et al., 2003). Additional aim ductile pressures would surpass early condensed pressure remains attendance kinds of reduction, such as autogenic reduction (Zhu, 1999; Xie et al., 2019). Lastly, heat of new concrete stands advanced that steadiness heat of situation throughout preservation stage, heat alteration throughout development is lesser than throughout preservation (Benaicha et al., 2015; Xu et al., 2014). Moreover, constant of thermic growth is a least situation and now rise by waterlessness. Figure 6 shows the formal shape for the fracturing of mass concrete (Maruyama and Lura, 2019; Zhang et al., 2015; 2017). Figure 7 shows Aggregate's influence in concrete (Metha and Monteiro, 2006). Figure 10 Displays Hydration model for cement hydration (Middendorf and Singh, 2006; Zacoeb et al., 2011). Figure 15 Displays Dye sensitized concrete solar cell
(Singh et al., 2017; Thomann and Lebet, 2008; Zhang et al., 2008). Figure 16 Shows Setup of tensile test (Wang et al., 2019; Taillet et al., 2014). Figure 11 shows general response Nano silica in Concrete. Figure 12 shows Part of Nano silica in Cementations organization. Figure 13 shows Result of Nano silica on great heat of captivating water of cement paste (Singh et al., 2013). Figure 14 shows Crack connection consequence in cement/CNTs composites (Hanus and Harris, 2013). Figure 17 shows SEM explanations the water concentration profits of cement. Figure 18 shows Grade of water concentration evaluation significances for cement (Matalkah and Soroushian, 2018). Figure 19 shows Effects of remaining structure (a), definite event (b) and active modulus (c) Feature of cement (Matalkah and Soroushian, 2018). Figure 20 shows Particulars of arrangement cement which cracks and De-bonding is obvious. Figure 21 shows Requirement of cement. Figure 22 shows Shallow presences cement. Figure 23 shows Graphic optical microscope explanations concrete.

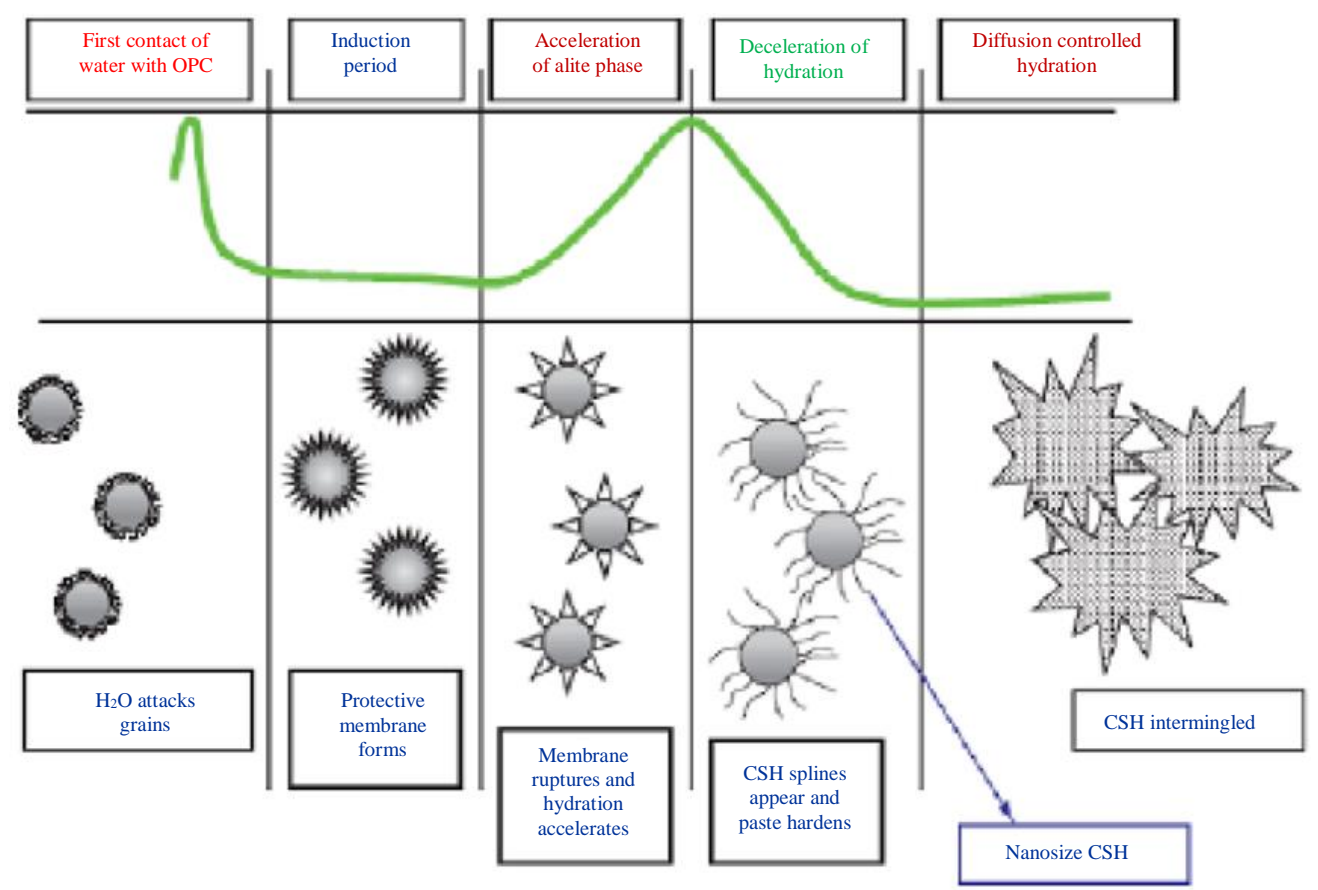

Fig. 10: Hydration model for cement hydration (Middendorf and Singh, 2006)

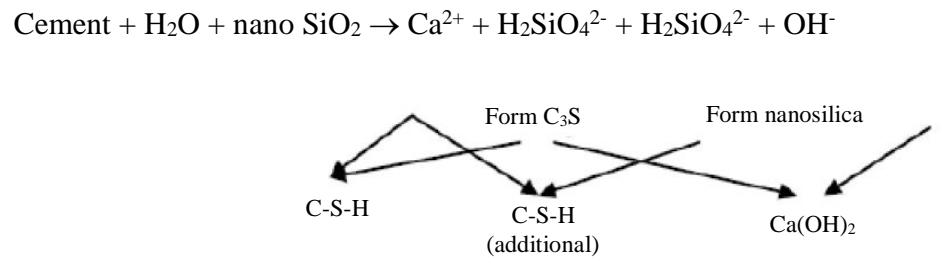

Fig. 11: The overall reaction nanosilica in Concrete (Singh et al., 2017) 


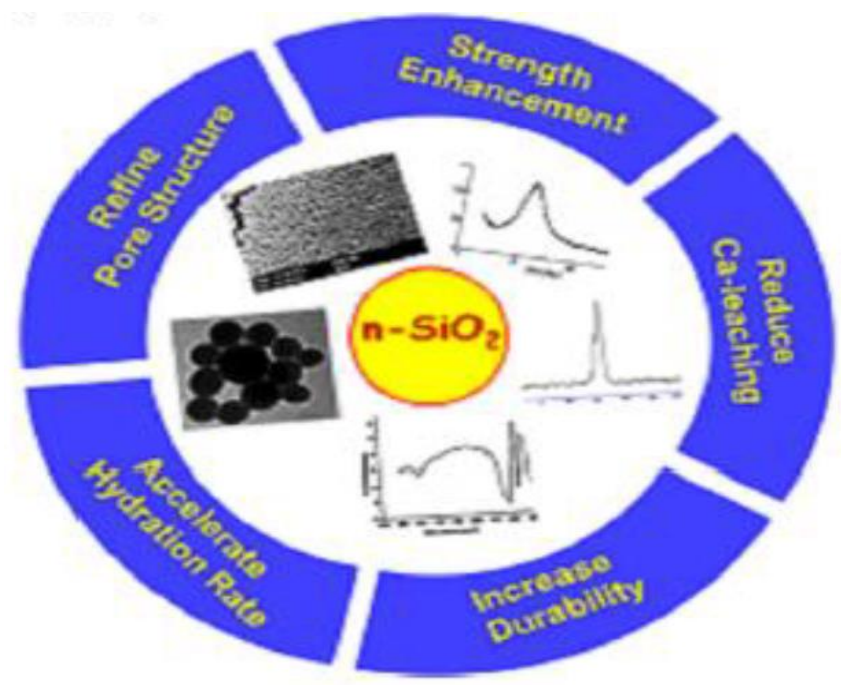

Fig. 12: Role of nanosilica in Cementitious system (Singh et al., 2017)

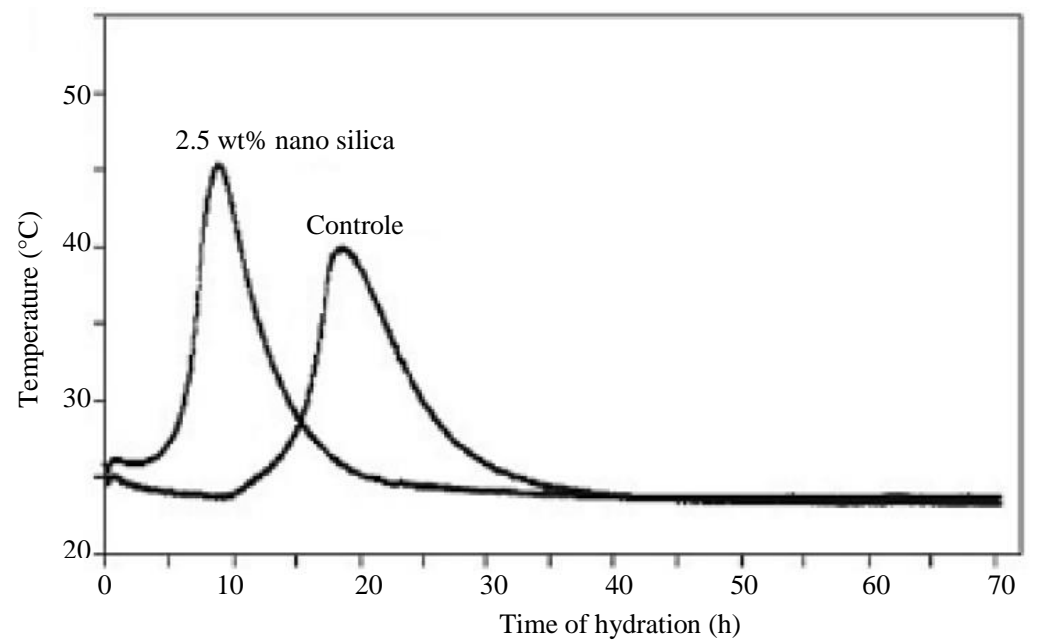

Fig. 13: Effect of Nano silica on high temperature of absorbing water of cement adhesive (Singh et al., 2013)

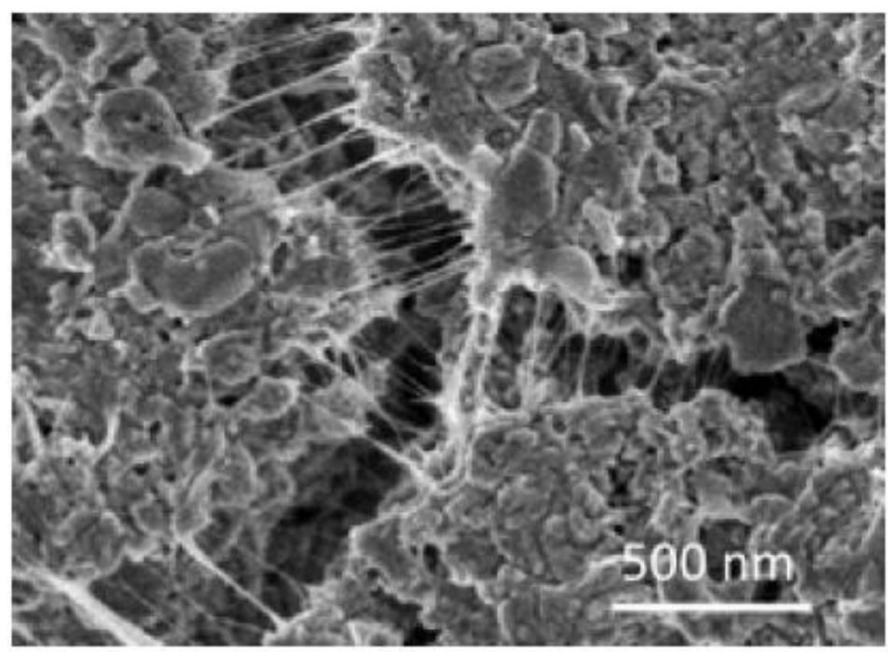

Fig. 14: Fissure joining result in cement/CNTs compounds (Hanus and Harris, 2013) 


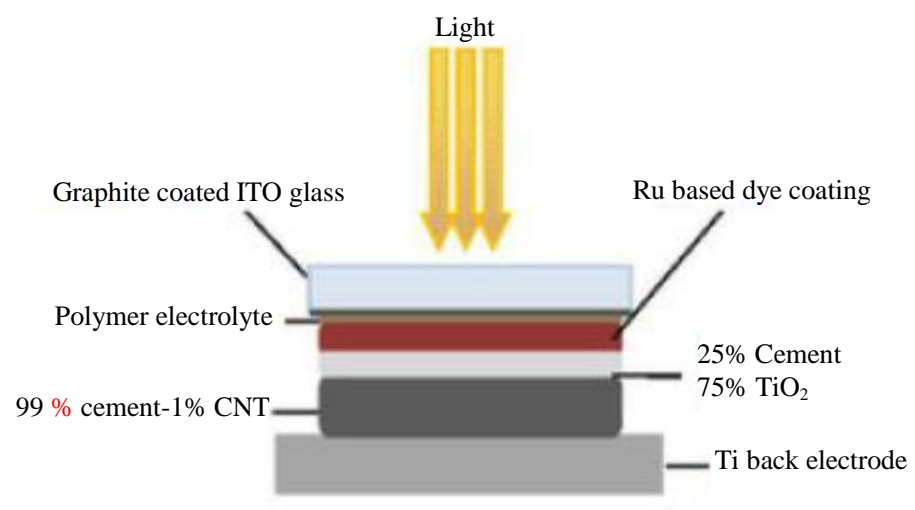

Fig. 15: Dye sensitized concrete solar cell (Singh et al., 2017)

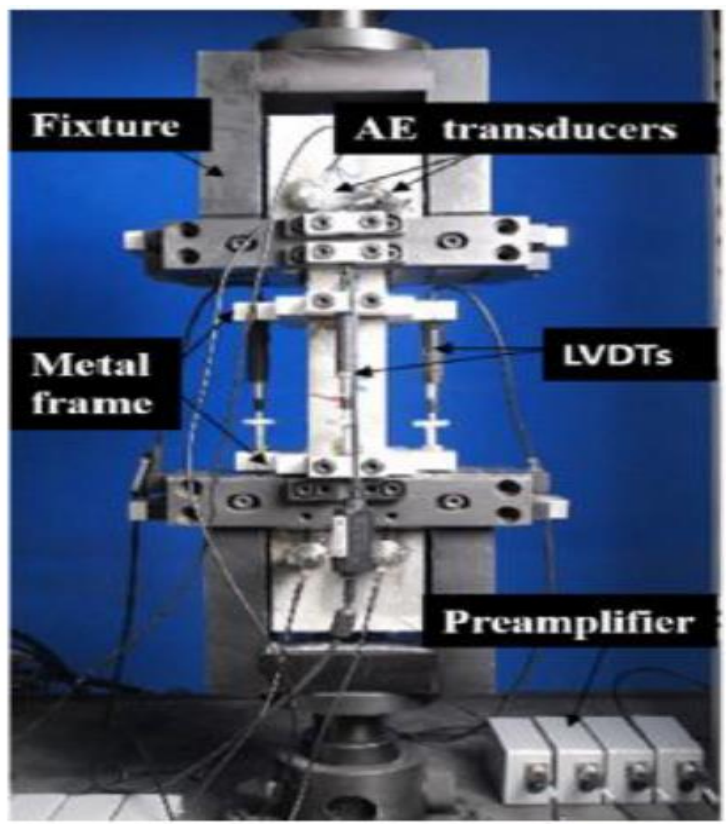

Fig. 16: Setup of tensile test (Wang et al., 2019)

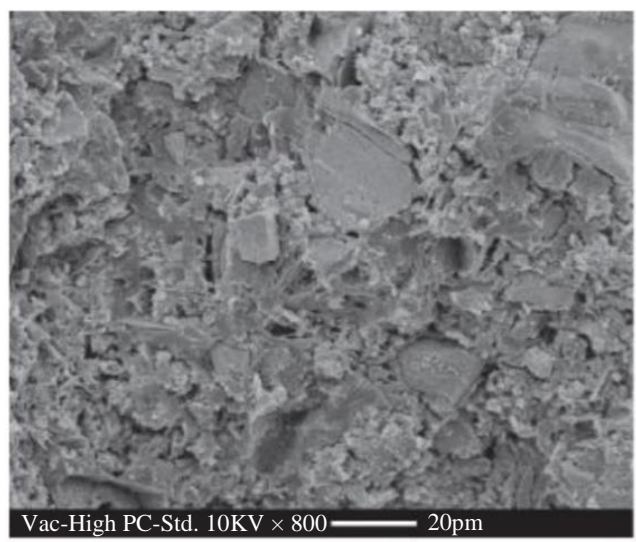

(a) Portland cement paste

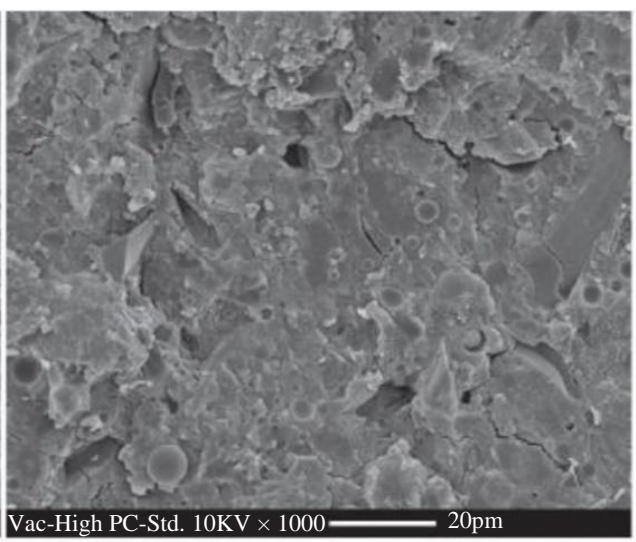

(b) Alkali aluminosilicate cement paste

Fig. 17: SEM descriptions the water absorption yields of cement (Matalkah and Soroushian, 2018) 


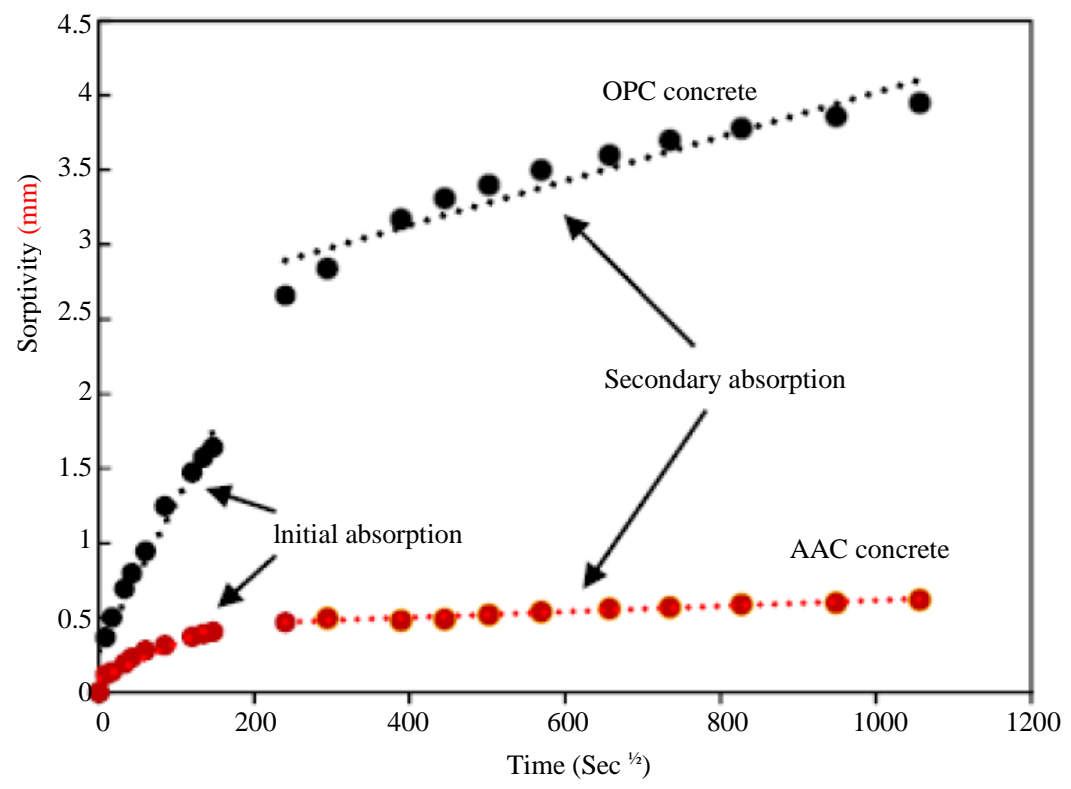

Fig. 18: Degree of water absorption assessment consequences for cement (Matalkah and Soroushian, 2018)

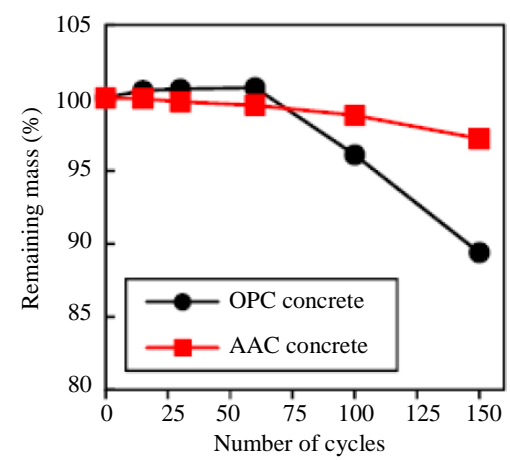

(a)

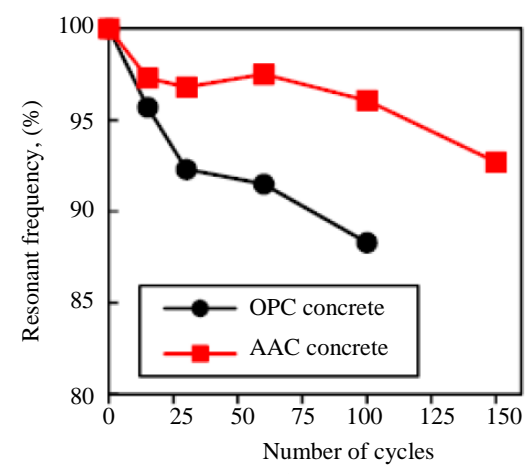

(b)

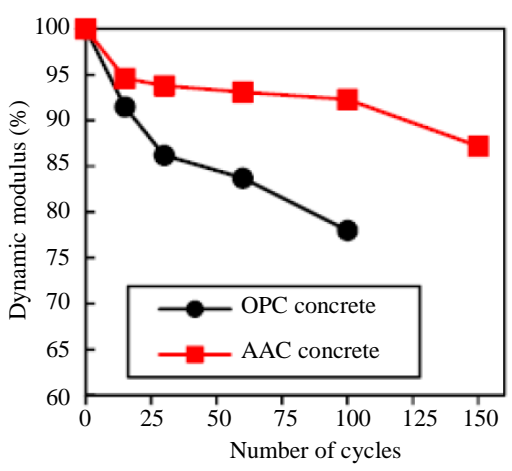

(c)

Fig. 19: Impacts of residual frame (a), resounding occurrence (b) and energetic modulus (c) Detail of cement (Matalkah and Soroushian, 2018)

Circumstance of substantial concrete constructions, warmness made by cement water absorption might origin fracturing owing to thermic tensions. Combination scheme of concrete applied such as constructions would examine explanation of powered possessions and made heats. Applying investigational project values, the water absorption warmness and expansion of condensed stability stay computed in direction to control in what way configuration of concrete and attendance of Additional cementing constituents impact the features of concrete and make a combination plan procedure (Singh et al., 2013; Spitz et al., 2018). Procedure support to control that combination project reduces water absorption heat for a particular condensed stability (Shon et al., 2018; 2016). In substantial constructions, exothermic of water absorption responses of concrete and thermic powered conduct of primary stage concrete could principal, if straining is controlled, expansion of pressing and ductile pressures. Ductile pressures surpass ductile stability, fracturing might happen, intimidating toughness of concrete. In direction to stop peril of fracturing in addition to Late Development, struggling concrete, application of accompaniments remain optional (Bourchy et al., 2019). Fly ash was determined extensively applied to advance concrete endurability throughout ages; though, the quantity of Fly ash was imperfect through comparatively small cement details in concrete. Rivera et al. (2015; Bourchy et al., 2019; Schackow et al., 2016; Singh et al., 2017; Shen et al., 2019). 
Kaveh Ostad-Ali-Askari et al. / American Journal of Engineering and Applied Sciences 2021, 14 (3): 409.429 DOI: 10.3844/ajassp.2021.409.429

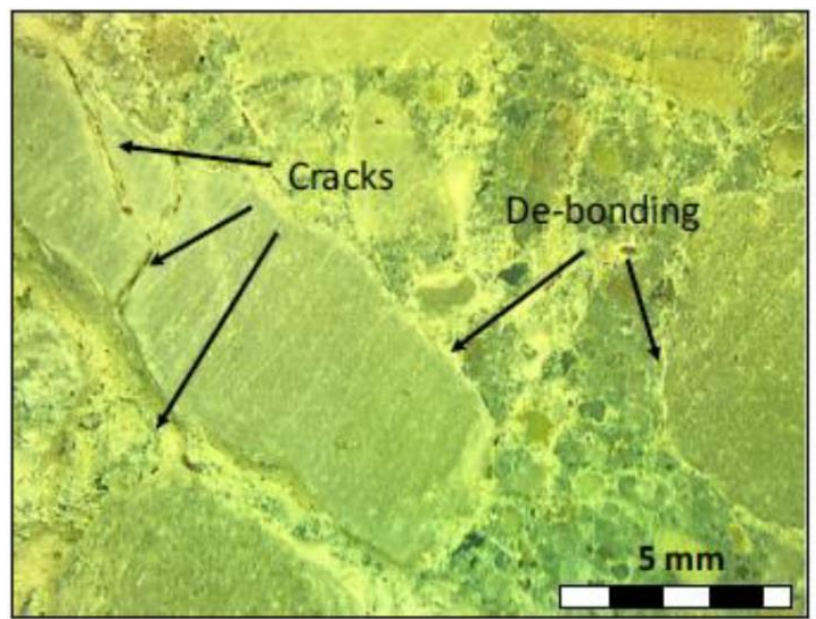

(a)

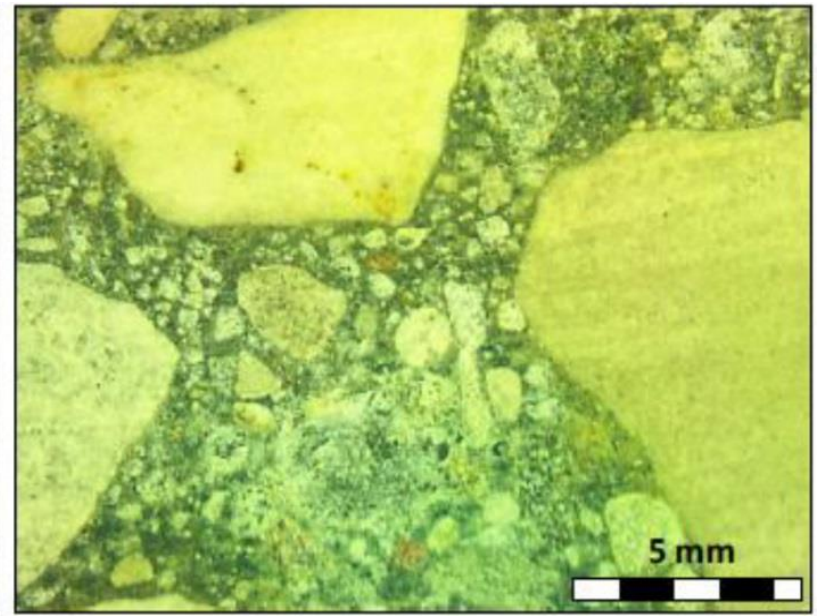

(b)

Fig. 20: Details of sequence cement (Matalkah and Soroushian, 2018); (a) Portland cement concerte; (b) Alkali aluminosilicate cement concerte
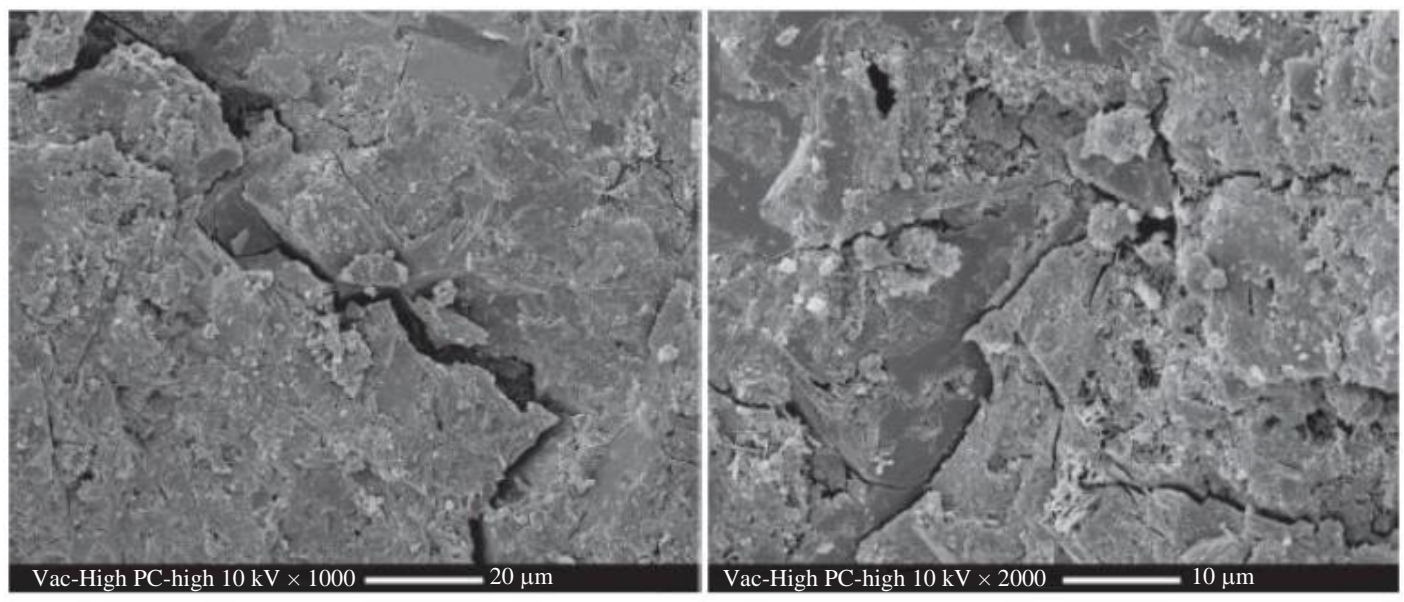

(a)
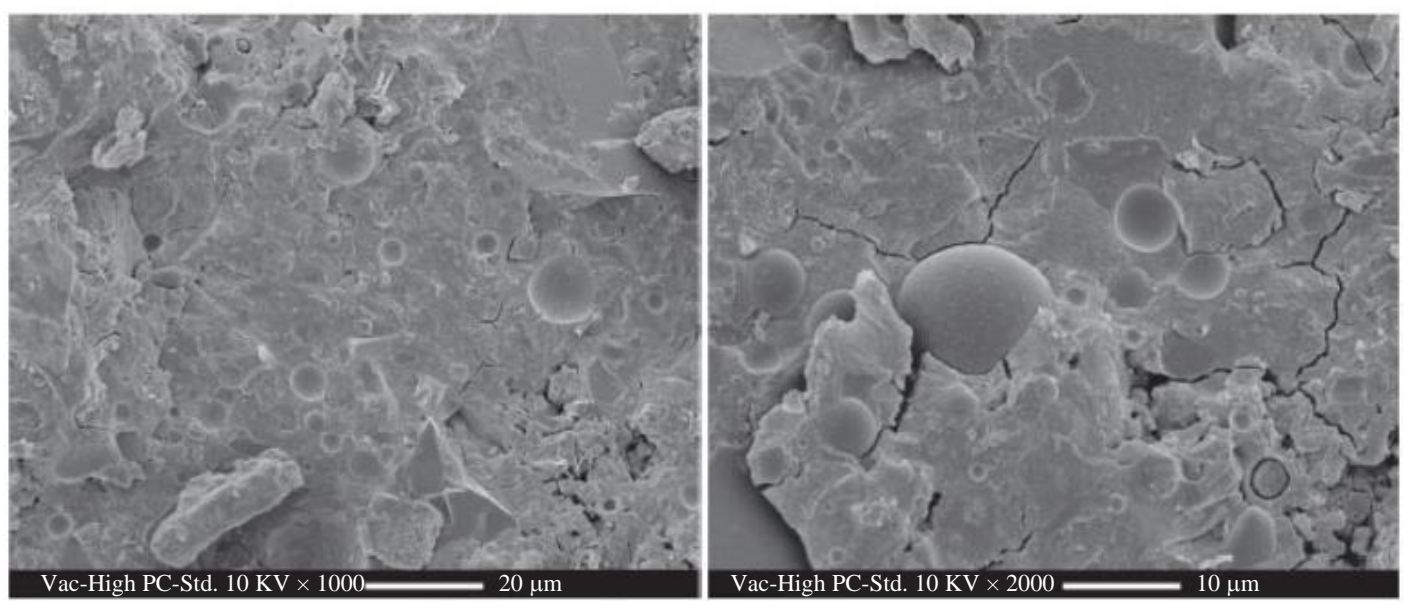

(b)

Fig. 21: Qualification of cement (Matalkah and Soroushian, 2018) (a) Portland cement paste; (b) Alkali aluminosilicate cement paste 
Kaveh Ostad-Ali-Askari et al. / American Journal of Engineering and Applied Sciences 2021, 14 (3): 409.429 DOI: 10.3844/ajassp.2021.409.429
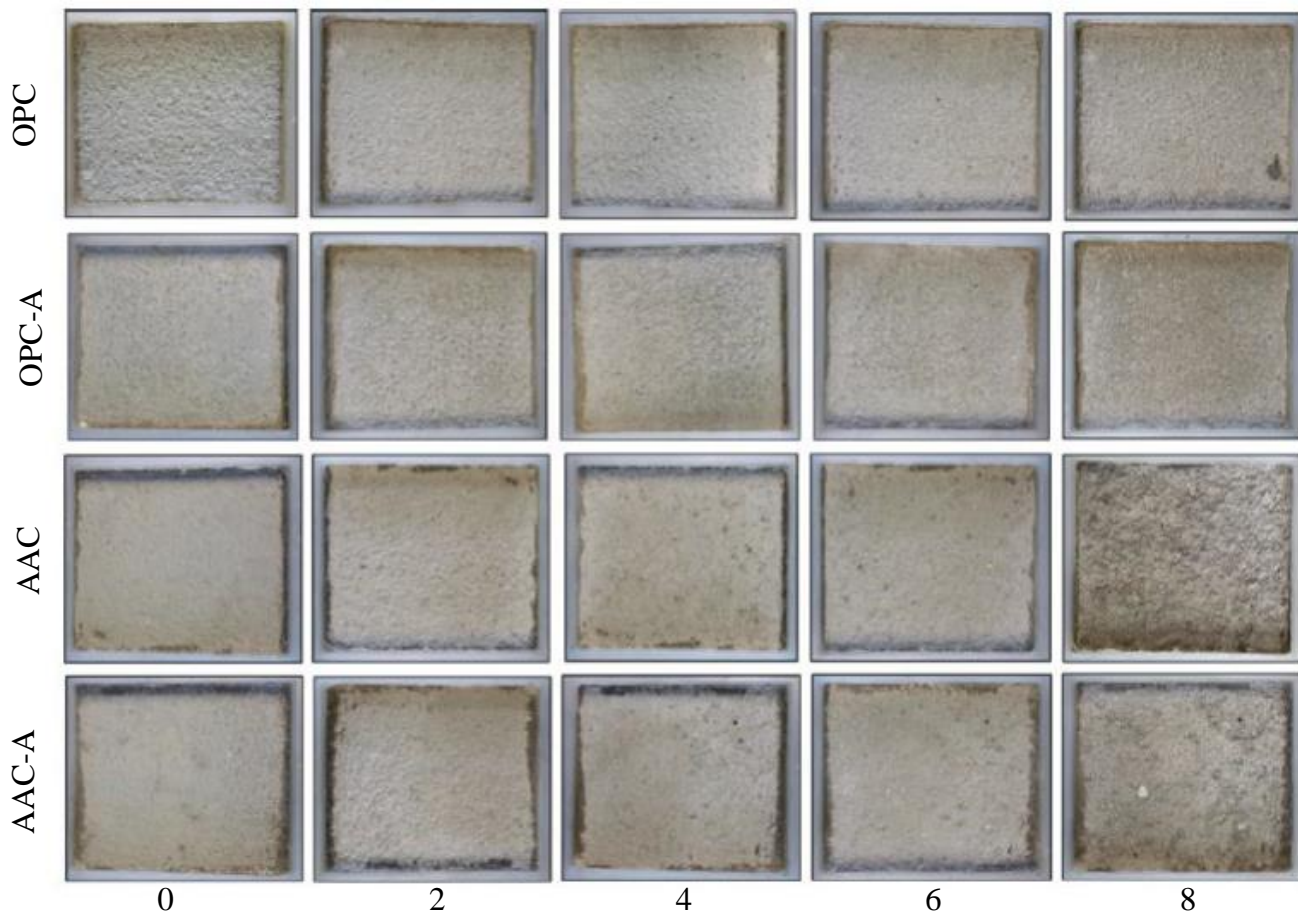

6

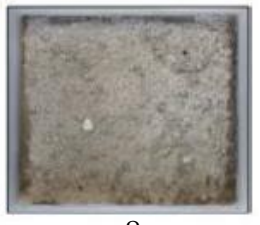

Number of cycles

Fig. 22: Superficial attendances cement (Matalkah and Soroushian, 2018)
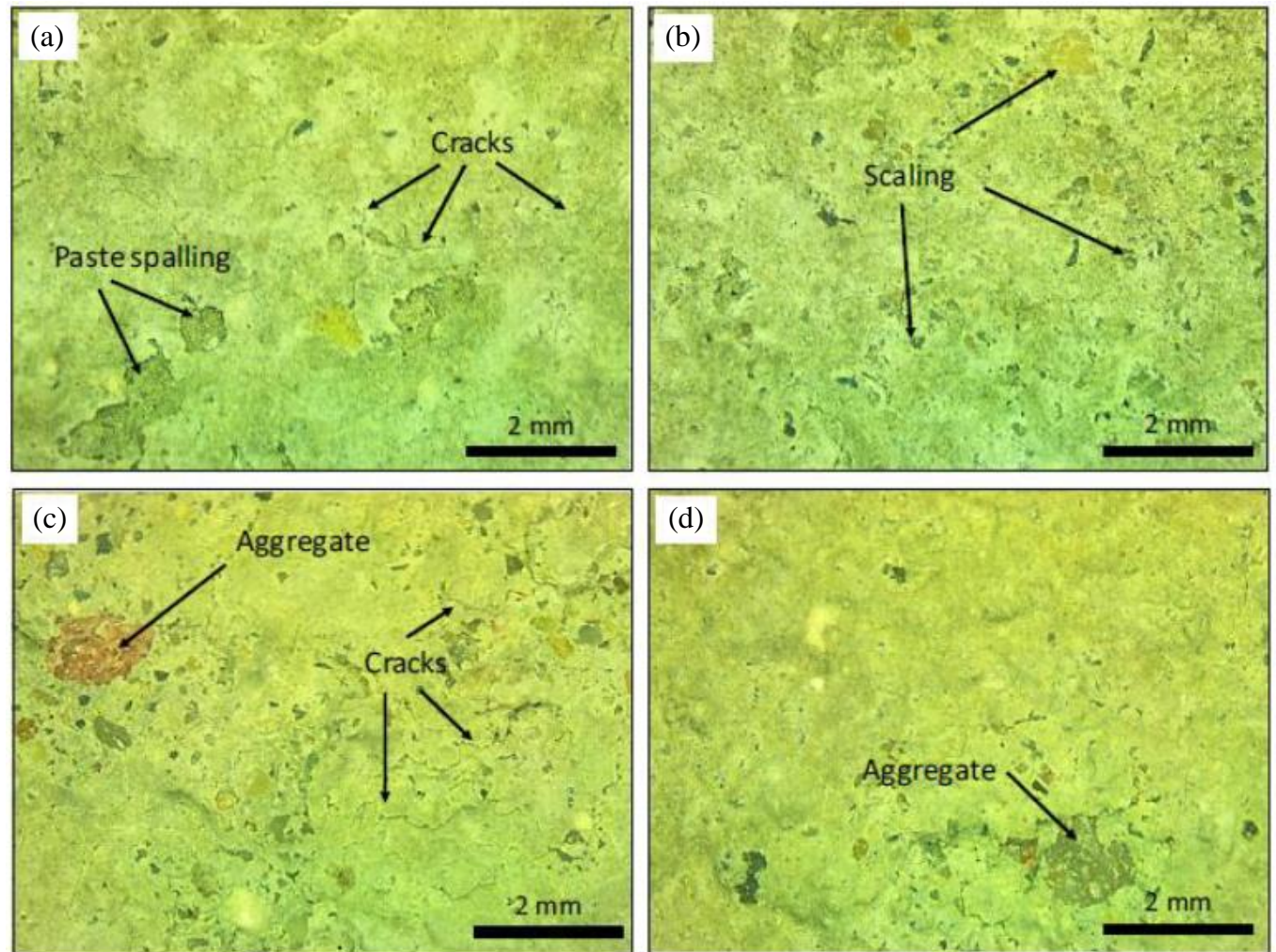

Fig. 23: Visual microscope descriptions concrete (Matalkah and Soroushian, 2018) 


\section{Acknowledgment}

This research was supported by the Department of Civil Engineering, School of Engineering, American University in Dubai, Dubai, P. O. Box 28282 United Arab and Isfahan University of the Technology. We thank our all authors who provided insight and expertise that greatly assisted the research.

\section{Author's Contributions}

All authors equally contributed in this work.

\section{Ethics}

The present Study and ethical aspect were approved by the Department of Civil Engineering, School of Engineering, American University in Dubai, Dubai, P. O. Box 28282 United Arab and Isfahan University of the Technology. The present study was approved by the Department of Civil Engineering, School of Engineering, American University in Dubai, Dubai, P. O. Box 28282 United Arab AND Isfahan University of Technology.

\section{References}

Abdelgader, H. S. (1996). Effect of the quantity of sand on the compressive strength of two-stage concrete. Magazine of Concrete Research, 48(177), 353-360. doi.org/10.1680/macr.1996.48.177.353

Abdelgader, H. S. (1999). How to design concrete produced by a two-stage concreting method. Cement and concrete research, 29(3), 331-337. doi.org/10.1016/S0008-8846(98)00215-4

Abdelgader, H. S., \& Ben-Zeitun, A. E. (2005). TENSILE STRENGTH OF TWO-STAGE CONCRETE MEASURED BY DOUBLE-PUNCH TESTS. In Role of Concrete in Nuclear Facilities (pp. 43-50). Thomas Telford Publishing.

Abdelgader, H. S., \& Elgalhud, A.A. (2008). Effect of grout proportions on strength of two stage concrete, Struct. Concr. 9 (3) 163-170. doi.org/10.1680/stco.2008.9.3.163

Abdelgader, H. S., \& Górski, J. (2003). Stress-strain relations and modulus of elasticity of two-stage concrete. Journal of materials in civil engineering, 15(4), 329-334. doi.org/10.1061/(ASCE)08991561(2003)15:4(329)

Abdelgader, H. S., Górski, J., Khatib, J., \& El-Baden, A. S. (2016). Two-stage concrete: effect of silica fume and superplasticizers on strength. Concrete Plant and Precast Technology, 82(3), 38-47.

Abdul Awal, A. S. M. (1984). Manufacture and properties of prepacked aggregate concrete.

Abdurrahmn, H., Abdelgader, H. S., Awal, A. A., \& ElBaden, A. S. (2014). Evaluation of energy dissipation in flexure for two stage concrete. Malaysian Journal of Civil Engineering, 26(3).
Abu-Tair, A. I., Lavery, D., Nadjai, A., Rigden, S. R., \& Ahmed, T. M. A. (2000). A new method for evaluating the surface roughness of concrete cut for repair or strengthening. Construction and building materials, 14(3), 171-176. doi.org/10.1016/S09500618(00)00016-7

ACI Committee 207. (1993). Cooling and Insulating Systems for Mass Concrete. Detroit-USA: American Concrete Institute; 1998.

ACI. (2005), Guide for the Use of Preplaced Aggregate Concrete for Structural and Mass Concrete Applications, vol. 304.1, American Concrete Institute, ACI Committee, 2005. p. 19.

Alev, Ü., Antsov, P., \& Kalamees, T. (2015). Air leakage of concrete floor and foundation junctions. Energy Procedia, 78, 2046-2051. doi.org/10.1016/j.egypro.2015.11.217

Assawamartbunlue, K., Surawattanawan, P., \& Luknongbu, W. (2019). Specific energy consumption of cement in Thailand. Energy Procedia, 156, 212-216. doi.org/10.1016/j.egypro.2018.11.130

Baltazar, L., Santana, J., Lopes, B., Rodrigues, M. P., \& Correia, J. R. (2014). Surface skin protection of concrete with silicate-based impregnations: Influence of the substrate roughness and moisture. Construction and Building Materials, 70, 191-200. doi.org/10.1016/j.conbuildmat.2014.07.071

Basnet, C. B., \& Panthi, K. K. (2018). Roughness evaluation in shotcrete-lined water tunnels with invert concrete based on cases from Nepal. Journal of Rock Mechanics and Geotechnical Engineering, 10(1), 42-59. doi.org/10.1016/j.jrmge.2017.07.006

Bayer, R. (2004). Use of preplaced aggregate concrete for mass concrete applications. Middle East Technical University, Turkey.

Benaicha, M., Jalbaud, O., Alaoui, A. H., \& Burtschell, Y. (2015). Correlation between the mechanical behavior and the ultrasonic velocity of fiber-reinforced concrete. Construction and Building Materials, 101, 702-709. doi.org/10.1016/j.conbuildmat.2015.10.047

Berodier, E. S. K. S. G., \& Scrivener, K. (2014). Understanding the Filler Effect on the Nucleation and Growth of C-S-H. Journal of the American Ceramic Society, 97(12), 3764-3773. doi.org/10.1111/jace.13177

Berodier, E., Gibson II, L. R., Burns, E., Roberts, L., \& Cheung, J. (2019). Robust production of sustainable concrete through the use of admixtures and in-transit concrete management systems. Cement and Concrete Composites, 101, 52-66. doi.org/10.1016/j.cemconcomp.2018.01.008

Bièvre, G., Lacroix, P., Oxarango, L., Goutaland, D., Monnot, G., \& Fargier, Y. (2017). Integration of geotechnical and geophysical techniques for the characterization of a small earth-filled canal dyke and the localization of water leakage. Journal of Applied Geophysics, 139, 1-15. doi.org/10.1016/j.jappgeo.2017.02.002 
Bonaldi, P., Fanelli, M., \& Giuseppetti, G. (1977). Displacement forecasting for concrete dams. International water power and dam construction, 29(9), 42-50.

Bourchy, A., Barnes, L., Bessette, L., Chalencon, F., Joron, A., \& Torrenti, J. M. (2019). Optimization of concrete mix design to account for strength and hydration heat in massive concrete structures. Cement and Concrete Composites, 103, 233-241. doi.org/10.1016/j.cemconcomp.2019.05.005

Bracci, J. M., Reinhorn, A. M., \& Mander, J. B. (1995). Seismic resistance of reinforced concrete frame structures designed for gravity loads: performance of structural system. Structural Journal, 92(5), 597-609. doi.org/10.14359/909

Breysse, D. (2012). Nondestructive evaluation of concrete strength: An historical review and a new perspective by combining NDT methods. Construction and Building Materials, 33, 139-163. doi.org/10.1016/j.conbuildmat.2011.12.103

Brown, E. T. (2017). Reducing risks in the investigation, design and construction of large concrete dams. Journal of Rock Mechanics and Geotechnical Engineering, 9(2), 197-209. doi.org/10.1016/j.jrmge.2016.11.002

Bujuan, L., Xinping, L., \& Zhaoyang, F. (1996). Study on the Monitoring and Forecasting Model for Deformation of Arch Dam [J]. Water Resources and Hydropower Engineering, 7.

Campos, A., Lopez, C. M., Blanco, A., \& Aguado, A. (2018). Effects of an internal sulfate attack and an alkali-aggregate reaction in a concrete dam. Construction and Building Materials, 166, 668-683. doi.org/10.1016/j.conbuildmat.2018.01.180

Cardarelli, E., Cercato, M., \& De Donno, G. (2018). Surface and borehole geophysics for the rehabilitation of a concrete dam (Penne, Central Italy). Engineering Geology, 241, 1-10. doi.org/10.1016/j.enggeo.2018.05.008

Casson, R. B. J., \& Davies, I. L. (1986). Performance of concrete backfilling materials for shafts and tunnels in rock formations. Volume 1: concrete selection and properties (No. EUR--10383 (V. 1)). Commission of the European Communities.

Champion, S., \& Davis, L. (1958). Grouted concrete construction. Reinf. Concrete Rev, 569-608.

Claybaugh, B. G., Earls, C. J., \& Ahmadi, A. K. (2004). Fatigue and strength performance of concrete-filled steel-grid bridge deck. Journal of Bridge Engineering, 9(5), 435-443. doi.org/10.1061/(ASCE)1084-0702(2004)9:5(435)

Coo, M., \& Pheeraphan, T. (2015). Effect of sand, fly ash and coarse aggregate gradation on preplaced aggregate concrete studied through factorial design. Construction and Building Materials, 93, 812-821. doi.org/10.1016/j.conbuildmat.2015.05.086
Coo, M., \& Pheeraphan, T. (2016). Effect of sand, fly ash and limestone powder on preplaced aggregate concrete mechanical properties and reinforced beam shear capacity. Construction and Building Materials, 120, 581-592. doi.org/10.1016/j.conbuildmat.2016.05.128

Diederich, P. (2010). Contribution à l'étude de l'influence des propriétés des fillers calcaires sur le comportement autoplaçant du béton (Doctoral dissertation, Université de Toulouse, Université Toulouse III-Paul Sabatier).

Fairbairn, E. M., Silvoso, M. M., Toledo Filho, R. D., Alves, J. L., \& Ebecken, N. F. (2004). Optimization of mass concrete construction using genetic algorithms. Computers \& structures, 82(2-3), 281299. doi.org/10.1016/j.compstruc.2003.08.008

Fanelli, M., \& Giuseppetti, G. (1982). Safety monitoring of concrete dams. International Water Power and Dam Construction, 34(11), 31-33.

Franck, A., \& De Belie, N. (2006). Concrete floor-bovine claw contact pressures related to floor roughness and deformation of the claw. Journal of dairy science, $89(8)$, 2952-2964. doi.org/10.3168/jds.S00220302(06)72567-X

Franck, A., Verhegghe, B., \& De Belie, N. (2008). The effect of concrete floor roughness on bovine claws using finite element analysis. Journal of dairy science, 91(1), 182192. doi.org/10.3168/jds.2007-0211

Gadri, K., \& Guettala, A. (2017). Evaluation of bond strength between sand concrete as new repair material and ordinary concrete substrate (The surface roughness effect). Construction and Building Materials, 157, 1133-1144. doi.org/10.1016/j.conbuildmat.2017.09.183

Goldstein, D. L., \& Smith, D. H. (1999). The analysis of the effects of experiential training on sojourners' cross cultural adaptability. International Journal of Intercultural Relations. doi.org/10.1016/S0147-1767(98)00030-3

Grigoriadis, K. (2016). Use of laser interferometry for measuring concrete substrate roughness in patch repairs. Automation in Construction, 64, 27-35. doi.org/10.1016/j.autcon.2015.12.025

Gu, C. S., \& Wu, Z. R. (2006). Safety monitoring of dams and dam foundations-theories \& methods and their application. Nanjing: Ho hai University Press (in Chinese).

Gu, C., Zhao, E., Jin, Y., \& Su, H. (2011). Singular value diagnosis in dam safety monitoring effect values. Science China Technological Sciences, 54(5), 1169-1176. doi.org/10.1007/s11431-011-4339-7

Guoqiang, L. Yi, Z.H. Su-Seng, P., \& Yongqi, L. Effective Young's modulus estimation of concrete, Cem. Concr. Res. 29 (1999) 1455-1462. doi.org/10.1016/S0008-8846(99)00119-2

Hanus, M. J., \& Harris, A. T. (2013). Nanotechnology innovations for the construction industry. Progress in materials science, 58(7), 1056-1102. doi.org/10.1016/j.pmatsci.2013.04.001 
Hariri-Ardebili, M. A., \& Saouma, V. E. (2016). Seismic fragility analysis of concrete dams: A state-of-the-art review. Engineering structures, 128, 374-399. doi.org/10.1016/j.engstruct.2016.09.034

Haselton, C. B. (2007). Assessing seismic collapse safety of modern reinforced concrete moment frame buildings (Doctoral dissertation, Stanford University). doi.org/10.1061/40944(249)22

He, X., Zheng, Z., Ma, M., Su, Y., Yang, J., Tan, H.,... \& Strnadel, B. (2020). New treatment technology: The use of wet-milling concrete slurry waste to substitute cement. Journal of Cleaner Production, 242, 118347. doi.org/10.1016/j.jclepro.2019.118347

He, Y., Zhang, X., Hooton, R. D., \& Zhang, X. (2017). Effects of interface roughness and interface adhesion on new-to-old concrete bonding. Construction and Building Materials, 151, 582-590. doi.org/10.1016/j.conbuildmat.2017.05.049

Higgins, C., \& Mitchell, H. (2001). Behavior of composite bridge decks with alternative shear connectors. Journal of Bridge Engineering, 6(1), 17-22. doi.org/10.1061/(ASCE)1084-0702(2001)6:1(17)

Hoła, J., Sadowski, Ł., Reiner, J., \& Stach, S. (2015). Usefulness of 3D surface roughness parameters for nondestructive evaluation of pull-off adhesion of concrete layers. Construction and Building Materials, 84, 111-120. doi.org/10.1016/j.conbuildmat.2015.03.014

Hong, L., Gu, X., \& Lin, F. (2014). Influence of aggregate surface roughness on mechanical properties of interface and concrete. Construction and Building Materials, 65, 338-349. doi.org/10.1016/j.conbuildmat.2014.04.131

Hudson, J. A., \& Feng, X. T. (2015). Rock Engineering Risk, ISBN-10: 9781138027015, CRC Press, Taylor and Francis. doi.org/10.1201/b18395

IFSTTAR, (2018). Recommendations for preventing disorders due to Delayed Ettringite Formation Technical Guide, 2018.

Issa, M. A., Issa, M. A., Islam, M. S., \& Chudnovsky, A. (2003). Fractal dimension-a measure of fracture roughness and toughness of concrete. Engineering Fracture Mechanics, 70(1), 125-137. doi.org/10.1016/S0013-7944(02)00019-X

Jeon, J., Lee, J., Shin, D., \& Park, H. (2009). Development of dam safety management system. Advances in Engineering Software, 40(8), 554-563. doi.org/10.1016/j.advengsoft.2008.10.009

Jiang, Y., Ling, T. C., Shi, C., \& Pan, S. Y. (2018). Characteristics of steel slags and their use in cement and concrete-A review. Resources, Conservation and Recycling, 136, 187-197. doi.org/10.1016/j.resconrec.2018.04.023

Jones, M. R., Zheng, L., \& Newlands, M. D. (2003). Estimation of the filler content required to minimise voids ratio in concrete. Magazine of concrete research, 55(2), 193-202. doi.org/10.1680/macr.2003.55.2.193
Joudi-Bahri, I., Lecomte, A., Ouezdou, M. B., \& Achour, T. (2012). Use of limestone sands and fillers in concrete without superplasticizer. Cement and Concrete Composites, 34(6), 771-780. doi.org/10.1016/j.cemconcomp.2012.02.010

Julio, E. N., Branco, F. A., \& Silva, V. D. (2004). Concrete-to-concrete bond strength. Influence of the roughness of the substrate surface. Construction and building materials, 18(9), 675-681. doi.org/10.1016/j.conbuildmat.2004.04.023

Justnes, H., Meland, I., Bjoergum, J. O., \& Krane, J. (1992). The mechanism of silica fume action in concrete studied by solid state 29Si NMR. In NMR Seminar, Guerville, France.

Kang, S. H., Jeong, Y., Tan, K. H., \& Moon, J. (2019). High-volume use of limestone in ultra-high performance fiber-reinforced concrete for reducing cement content and autogenous shrinkage. Construction and Building Materials, 213, 292-305. doi.org/10.1016/j.conbuildmat.2019.04.091

Karsan, I. D., \& Jirsa, J. O. (1969). Behavior of concrete under compressive loadings. Journal of the Structural Division. doi.org/10.1061/JSDEAG.0002424

Khayat, K. H., \& Libre, N. A. (2014). Automated measurement and control of concrete properties in a ready mix truck with VERIFI (No. NUTC R335). Missouri University of Science and Technology. Center for Transportation Infrastructure and Safety.

Lastra-González, P., Indacoechea-Vega, I., CalzadaPérez, M. A., Castro-Fresno, D., \& Carpio-García, J. (2017). Analysis of the skid resistance and adherence between layers of asphalt concretes modified by dry way with polymeric waste. Construction and Building Materials, 133, 163-170. doi.org/10.1016/j.conbuildmat.2016.12.063

Lee, B., \& Oh, S. (2018). Modified electrical survey for effective leakage detection at concrete hydraulic facilities. Journal of Applied Geophysics, 149, 114-130. doi.org/10.1016/j.jappgeo.2017.08.006

Liu, J. C., Sue, M. L., \& Kou, C. H. (2009). Estimating the strength of concrete using surface rebound value and design parameters of concrete material. Tamkang Journal of Science and Engineering, 12(1), 1-7.

Liu, Z., Wang, X., Zhang, Q., \& Huang, C. (2019). Empirical mode decomposition based hybrid ensemble model for electrical energy consumption forecasting of the cement grinding process. Measurement, 138, 314-324. doi.org/10.1016/j.measurement.2019.02.062

Maruyama, I., \& Lura, P. (2019). Properties of early-age concrete relevant to cracking in massive concrete. Cement and Concrete Research, 123, 105770. doi.org/10.1016/j.cemconres.2019.05.015

Matalkah, F., \& Soroushian, P. (2018). Freeze thaw and deicer salt scaling resistance of concrete prepared with alkali aluminosilicate cement. Construction and Building Materials, 163, 200-213. doi.org/10.1016/j.conbuildmat.2017.12.119 
Mazighi, H., \& Mihoubi, M. K. (2018). Study of the effect of upstream slope on water pressure in concrete gravity dam. Procedia Structural Integrity, 13, 1438-1441. doi.org/10.1016/j.prostr.2018.12.298

Meng, Y., Fang, Y., Wan, M., Su, Q., Tian, B., \& Tong, F. (2019). Research of concrete dam leakage detection based on anomaly current field of reservoir water. Journal of applied geophysics, 160, 242-253. doi.org/10.1016/j.jappgeo.2018.11.016

Metha, K. P., \& Monteiro, P. J. M. (2006). Concrete Microstructure, Properties and Concretes, third ed., McGraw-Hill, University of California at Berkeley, 2006.

Middendorf, B., \& Singh, N.B. (2006). Cement International. 4 (2006) 80-86.

Molines, J., \& Medina, J. R. (2015). Calibration of overtopping roughness factors for concrete armor units in non-breaking conditions using the CLASH database. Coastal Engineering, 96, 62-70. doi.org/10.1016/j.coastaleng.2014.11.008

Moradloo, A. J., Adib, A., \& Pirooznia, A. (2019). Damage analysis of arch concrete dams subjected to underwater explosion. Applied Mathematical Modelling, 75, 709734. doi.org/10.1016/j.apm.2019.04.064

Morohashi, N. Meyer, C., \& Abdelgader, H.S. (2013). Concrete with recycled aggregates two-stage production method, CPI-Concr. Plant Int. 4 (2013) 34-41.

Mostofinejad, N. (2005). Prediction of the modulus of elasticity of high strength concrete, Iran. J. Sci. Technol., Trans. B Eng. 29 (B3) (2005).

Najjar, M. F. (2016). Innovating Two-Stage Concrete with Improved Rheological, Mechanical and Durability Properties.

Najjar, M. F., \& Abdelgader, H. S. (2009). Underwater concreting by using two-stage (preplaced aggregate) concrete. In Proceedings of the 1st International Conference on Concrete Technology, Tabriz, Iran XX (Vol. 1).

Najjar, M. F., Soliman, A. M., \& Nehdi, M. L. (2014). Critical overview of two-stage concrete: Properties and applications. Construction and Building Materials, 62, 47-58. doi.org/10.1016/j.conbuildmat.2014.03.021

Nejad, A. B. (2000). Improvement of Cement and Sand Consumption in Concrete Volume, Fourth Iran Dam Construction Conference, Tehran.

Neville, A. M. (1995). Properties of concrete (Vol. 4). London: Longman.

Niklasch, C., \& Herrmann, N. (2009). Nonlinear fluidstructure interaction calculation of the leakage behaviour of cracked concrete walls. Nuclear Engineering and Design, 239(9), 1628-1640. doi.org/10.1016/j.nucengdes.2008.09.001

Nowek, A., Kaszubski, P., Abdelgader, H. S., \& Górski, J. (2007). Effect of admixtures on fresh grout and twostage (pre-placed aggregate) concrete. Structural Concrete, 8(1), 17-23. doi.org/10.1680/stco.2007.8.1.17
O’Malley, J., \& Abdelgader, H. S. (2010). Investigation into viability of using two-stage (pre-placed aggregate) concrete in Irish setting. Frontiers of Architecture and Civil Engineering in China, 4(1), 127-132. doi.org/10.1007/s11709-010-0007-4

Onoue, K. (2019). Energy consumption characteristics of concrete using granulated blast-furnace slag sand related to nucleation and propagation of microcracks. Construction and Building Materials, 218, 404-412. doi.org/10.1016/j.conbuildmat.2019.05.141

Pant, D. R., Wijeyewickrema, A. C., \& ElGawady, M. A. (2013). Appropriate viscous damping for nonlinear time-history analysis of base-isolated reinforced concrete buildings. Earthquake Engineering \& Structural Dynamics, 42(15), 2321-2339. doi.org/10.1002/eqe.2328

Park, R., Priestley, M. J., \& Gill, W. D. (1982). Ductility of square-confined concrete columns. Journal of the structural division, 108(4), 929-950. doi.org/10.1061/JSDEAG.0005933

Paulay, T., \& Priestley, M. N. (1992). Seismic design of reinforced concrete and masonry buildings. doi.org/10.1002/9780470172841

Pelisser, F., Barcelos, A., Santos, D., Peterson, M., \& Bernardin, A. M. (2012). Lightweight concrete production with low Portland cement consumption. Journal of Cleaner Production, 23(1), 68-74. doi.org/10.1016/j.jclepro.2011.10.010

Pelisser, F., Vieira, A., \& Bernardin, A. M. (2018). Efficient self-compacting concrete with low cement consumption. Journal of Cleaner Production, 175, 324-332. doi.org/10.1016/j.jclepro.2017.12.084

Pereira, S., Magalhaes, F., Gomes, J. P., Cunha, A., \& Lemos, J. V. (2018). Dynamic monitoring of a concrete arch dam during the first filling of the reservoir. Engineering Structures, 174, 548-560. doi.org/10.1016/j.engstruct.2018.07.076

Popovics, S. (1973). A numerical approach to the complete stress-strain curve of concrete. Cement and concrete research, 3(5), 583-599. doi.org/10.1016/0008-8846(73)90096-3

Poul, M. K., \& Zerva, A. (2018). Nonlinear dynamic response of concrete gravity dams considering the deconvolution process. Soil Dynamics and Earthquake Engineering, 109, 324-338. doi.org/10.1016/j.soildyn.2018.03.025

Qin, Z., Lai, Y., Tian, Y., \& Yu, F. (2019). Frostheaving mechanical model for concrete face slabs of earthen dams in cold regions. Cold Regions Science and Technology, 161, 91-98. doi.org/10.1016/j.coldregions.2019.03.009

Rivera, F., Martínez, P., Castro, J., \& López, M. (2015). Massive volume fly-ash concrete: A more sustainable material with fly ash replacing cement and aggregates. Cement and Concrete Composites, 63, 104-112. doi.org/10.1016/j.cemconcomp.2015.08.001 
Sanchez, F., \& Sobolev, K. (2010). Nanotechnology in concrete-a review. Construction and building materials, 24(11), 2060-2071. doi.org/10.1016/j.conbuildmat.2010.03.014

Santos, P. M., \& Julio, E. N. (2007). Correlation between concrete-to-concrete bond strength and the roughness of the substrate surface. Construction and Building Materials, 21(8), 1688-1695. doi.org/10.1016/j.conbuildmat.2006.05.044

Santos, P. M., \& Júlio, E. N. (2013). A state-of-the-art review on roughness quantification methods for concrete surfaces. Construction and Building Materials, 38, 912923. doi.org/10.1016/j.conbuildmat.2012.09.045

Satyarno, I., Solehudin, A. P., Meyarto, C., Hadiyatmoko, D., Muhammad, P., \& Afnan, R. (2014). Practical method for mix design of cement-based grout. Procedia Engineering, 95, 356-365. doi.org/10.1016/j.proeng.2014.12.194

Schackow, A., Effting, C., Gomes, I. R., Patruni, I. Z., Vicenzi, F., \& Kramel, C. (2016). Temperature variation in concrete samples due to cement hydration. Applied thermal engineering, 103, 1362-1369. doi.org/10.1016/j.applthermaleng.2016.05.048

Selçuk, L., \& Gökçe, H. S. (2015). Estimation of the compressive strength of concrete under point load and its approach to strength criterions. KSCE Journal of Civil Engineering, 19(6), 1767-1774. doi.org/10.1007/s12205-015-1303-2

Shaker, F., Rashad, A., \& Allam, M. (2018). Properties of concrete incorporating locally produced Portland limestone cement. Ain Shams Engineering Journal, 9(4), 2301-2309. doi.org/10.1016/j.asej.2017.04.005

Shen, Y., Wang, Y., Yang, Y., Sun, Q., Luo, T., \& Zhang, H. (2019). Influence of surface roughness and hydrophilicity on bonding strength of concrete-rock interface. Construction and Building Materials, 213, 156-166. doi.org/10.1016/j.conbuildmat.2019.04.078

Shon, C. S., Abdigaliyev, A., Bagitova, S., Chung, C. W., \& Kim, D. (2018). Determination of air-void system and modified frost resistance number for freeze-thaw resistance evaluation of ternary blended concrete made of ordinary Portland cement/silica fume/class F fly ash. Cold Regions Science and Technology, 155, 127-136. doi.org/10.1016/j.coldregions.2018.08.003

Singh, L. P., Karade, S. R., Bhattacharyya, S. K., Yousuf, M. M., \& Ahalawat, S. (2013). Beneficial role of nanosilica in cement based materials-A review. Construction and Building Materials, 47, 1069-1077. doi.org/10.1016/j.conbuildmat.2013.05.052

Singh, N. B., Kalra, M., \& Saxena, S. K. (2017). Nanoscience of cement and concrete. Materials today: proceedings, 4(4), 5478-5487. doi.org/10.1016/j.matpr.2017.06.003

Song, J., Gu, C., Su, H., Gu, H., \& Huang, X. (2016). Observed displacement data-based identification method of structural damage in concrete dam. Engineering Failure Analysis, 66, 202-211. doi.org/10.1016/j.engfailanal.2016.04.013
Song, X. F., Wei, J. F., \& He, T. S. (2009). A method to repair concrete leakage through cracks by synthesizing super-absorbent resin in situ. Construction and Building Materials, 23(1), 386-391. doi.org/10.1016/j.conbuildmat.2007.11.009

Spitz, N., Coniglio, N., El Mansori, M., Montagne, A., \& Mezghani, S. (2018). Quantitative and representative adherence assessment of coated and uncoated concreteformwork. Surface and Coatings technology, 352, 247-256. doi.org/10.1016/j.surfcoat.2018.07.098

Stroeven, P. (2000). A stereological approach to roughness of fracture surfaces and tortuosity of transport paths in concrete. Cement and Concrete Composites, 22(5), 331-341. doi.org/10.1016/S09589465(00)00018-4

Taillet, E., Lataste, J. F., Rivard, P., \& Denis, A. (2014). Nondestructive evaluation of cracks in massive concrete using normal dc resistivity logging. NDT \& E International, 63, 11-20. doi.org/10.1016/j.ndteint.2014.01.001

Thomann, M., \& Lebet, J. P. (2008). A mechanical model for connections by adherence for steel-concrete composite beams. Engineering structures, 30(1), 163173. doi.org/10.1016/j.engstruct.2007.03.016

Wang, J. Y., Chen, Z. Z., \& Wu, K. (2019). Properties of calcium sulfoaluminate cement made ultra-high performance concrete: Tensile performance, acoustic emission monitoring of damage evolution and microstructure. Construction and Building Materials, 208, 767-779. doi.org/10.1016/j.conbuildmat.2019.03.057

Wang, J., \& Liu, A. L. (2008). Application of ABAQUS to calculation of creep thermal stress of mass concrete [J]. Journal of Hohai University (Natural Sciences), 36(4), 0532-0537.

Wong, T. S., \& Lim, C. K. (2006). Effect of loss model on evaluation of Manning roughness coefficient of experimental concrete catchment. Journal of hydrology, 331(1-2), 205-218. doi.org/10.1016/j.jhydrol.2006.05.009

Wu, L. X., Yin, Z. R., \& Zhong, Y. P. (2003). Restudy on digital mine: Characteristics, framework and key technologies. Journal of china coal society, 28(1), 1-7.

Wu, Z., Li, J., Gu, C., \& Su, H. (2007). Review on hidden trouble detection and health diagnosis of hydraulic concrete structures. Science in China Series E: Technological Sciences, 50(1), 34-50. doi.org/10.1007/s11431-007-6003-9

Xie, N., Dang, Y., \& Shi, X. (2019). New insights into how $\mathrm{MgCl} 2$ deteriorates Portland cement concrete. Cement and Concrete Research, 120, 244-255. doi.org/10.1016/j.cemconres.2019.03.026

Xu, B., Liu, B., Zheng, D., Chen, L., \& Wu, C. (2012). Analysis method of thermal dam deformation. Science China Technological Sciences, 55(6), 1765-1772. doi.org/10.1007/s11431-012-4839-0 
Xu, Z. K., Xiong, W., Wei, B. W., \& Li, L. H. (2014). A new method of dam safety monitoring for identifying displacement mutation. In Applied Mechanics and Materials (Vol. 687, pp. 925-928). Trans Tech Publications Ltd.

doi.org/10.4028/www.scientific.net/AMM.687691.925

Yassin, M. H. M. (1994). Nonlinear analysis of prestressed concrete sructures under monotonic and cyclic loads. University of California, Berkeley.

Yoon, J. Y., \& Kim, J. H. (2018). Evaluation on the consumption and performance of polycarboxylates in cement-based materials. Construction and Building Materials, 158, 423-431. doi.org/10.1016/j.conbuildmat.2017.10.004

Yoshitake, I., Kuroda, Y., Watada, Y., \& Kim, Y. J. (2016). Fatigue performance of steel-concrete composite slabs with a cementitious adhesive subjected to water leakage. Construction and Building Materials, 111, 22-29.

doi.org/10.1016/j.conbuildmat.2016.02.048

Zacoeb, A., \& Ishibashi, K. (2011). Alternative Method for Concrete Structures Compressive Strength Estimation with Small-Scale Destruction. Journal of Civil Engineering and Architecture, 5(2). doi.org/10.17265/1934-7359/2011.02.007
Zhang, J. H., Wang, J., \& Chai, L. S. (2015). Research on the hysteresis characteristic of concrete dam deformation and the influence of dam types. Hydropower and Pumped Storage, 1(4), 9-12.

Zhang, J. H., Wang, J., \& Chai, L. S. (2017). Factors influencing hysteresis characteristics of concrete dam deformation. Water Science and Engineering, 10(2), 166-174. doi.org/10.1016/j.wse.2017.03.007

Zhang, J. P., Li, L. B., \& Lu, Z. C. (2008). Review and prospect of dam safety monitoring. Journal of China Institute of Water Resources and Hydropower Research, 4(06), 317-322.

Zhu, B. F. (1999). Temperature stress and temperature control of mass concrete. China Electric Power Press, Beijing.

Zhu, C., Lv, J., Chen, L., Lin, W., Zhang, J., Yang, J., \& Feng, J. (2019). Dark, heat-reflective, anti-ice rain and superhydrophobic cement concrete surfaces. Construction and Building Materials, 220, 21-28. doi.org/10.1016/j.conbuildmat.2019.05.188

Zou, X., Chao, A., Tian, Y., Wu, N., Zhang, H., Yu, T. Y., \& Wang, X. (2012). An experimental study on the concrete hydration process using Fabry-Perot fiber optic temperature sensors. Measurement, 45(5), 1077-1082. doi.org/10.1016/j.measurement.2012.01.034 